IZA DP No. 10303

Moving Up or Down?

Immigration and the Selection of Natives across

Occupations and Locations

Javier Ortega

Gregory Verdugo

October 2016 


\title{
Moving Up or Down? Immigration and the Selection of Natives across Occupations and Locations
}

\author{
Javier Ortega \\ City University London, \\ CReAM and IZA \\ Gregory Verdugo \\ CES, Université Paris 1, \\ OFCE and IZA \\ Discussion Paper No. 10303 \\ October 2016 \\ IZA
P.O. Box 7240
53072 Bonn
Germany \\ Phone: +49-228-3894-0 \\ Fax: +49-228-3894-180 \\ E-mail: iza@iza.org
}

\begin{abstract}
Any opinions expressed here are those of the author(s) and not those of IZA. Research published in this series may include views on policy, but the institute itself takes no institutional policy positions. The IZA research network is committed to the IZA Guiding Principles of Research Integrity.

The Institute for the Study of Labor (IZA) in Bonn is a local and virtual international research center and a place of communication between science, politics and business. IZA is an independent nonprofit organization supported by Deutsche Post Foundation. The center is associated with the University of Bonn and offers a stimulating research environment through its international network, workshops and conferences, data service, project support, research visits and doctoral program. IZA engages in (i) original and internationally competitive research in all fields of labor economics, (ii) development of policy concepts, and (iii) dissemination of research results and concepts to the interested public.
\end{abstract}

IZA Discussion Papers often represent preliminary work and are circulated to encourage discussion. Citation of such a paper should account for its provisional character. A revised version may be available directly from the author. 


\title{
ABSTRACT \\ Moving Up or Down? Immigration and the Selection of Natives across Occupations and Locations*
}

\begin{abstract}
Exploiting a large French panel for 1976-2007, we examine the impact of low-educated immigration on the labour market outcomes of blue-collar natives initially in jobs where immigrants became overrepresented in the last decades. Immigrant inflows generate substantial reallocations of natives across locations and occupations. Location movers are negatively selected while occupation movers are positively selected and move towards better paid-jobs characterised by less routine tasks. As a result, controlling for composition effects has an important quantitative impact on the estimated effects of immigration. Low-educated immigration generally lowers the wages of blue-collar workers, but its impact is heterogeneous across sectors.
\end{abstract}

JEL Classification: J15, J31

Keywords: immigration, wages, employment

Corresponding author:

Javier Ortega

Department of Economics

City University London

Northampton Square

London EC1V OHB

United Kingdom

E-mail: javier.ortega.1@city.ac.uk

\footnotetext{
"An earlier version of this paper circulated under the title: "The Impact of Immigration on the Local Labor Market Outcomes of Blue Collar Workers: Panel Data Evidence". We thank the INSEE for making the data available. The Census data used in this paper are available upon request for researchers from the $\mathrm{CMH}$. The authors accessed the DADS data via the Centre d'Accès Sécurisé Distant (CASD), dedicated to the use of authorized researchers, following the approval of the Comité français du secret statistique. The views expressed here do not necessarily reflect those of any of the organizations with which the authors are affiliated. We also thank Denis Fougère, Kyle Mangum, Manon Dos Santos, Muriel Roger, Ahmed Tritah and seminar participants at AMSE, Norface, SOLE, IZA-SOLE, CEP (LSE), and ESSLE-CEPR for very useful suggestions. This research was supported by a French state grant (grant no. ANR-10-EQPX-17) (Centre d'accès sécurisé aux données (CASD)) and the LABEX OSE of the Paris School of Economics (ANR-10-LABX_93-01). This research was also supported by CEPREMAP's Programme Travail and the "Flash Asile" programme of the French Agence Nationale de la Recherche.
} 


\section{Introduction}

A substantial part of the public concern about immigration in developed countries relates to the impact immigration may have on the labour market outcomes of natives. However, while much progress has been made, the assessment of whether and how immigration changes natives' labour market outcomes still faces many empirical challenges. While under competitive labour markets an increase in immigration should lower the wages of competing workers, the identification of the groups of natives directly competing with immigrants remains a controversial issue.

In particular, immigrants may be quite different from natives with a similar educational level because of their lack of language fluency or the lower value of foreign education in the host country (Friedberg, 2000). Indeed, several studies indicate that immigrants "downgrade" at arrival in the sense that they work in jobs of much lower quality than natives with similar education and experience (Dustmann and Preston, 2012). As a result, when a recent strand of the literature proposed to use education and experience to define the groups of immigrants and natives in competition (see e.g. Borjas, 2003, or Aydemir and Borjas, 2007), some papers responded that, within such groups, immigrants and natives might not really compete for the same jobs (Dustmann, Frattini and Preston, 2013) or might be imperfect substitutes (Ottaviano and Peri, 2012). ${ }^{1}$

In this paper, instead of making assumptions about which observable individual characteristics make natives and immigrants similar, we propose to examine what happened to natives initially in jobs where immigrants became overrepresented in the last decades. Indeed, native workers employed in jobs that have attracted a large share of foreign workers are more

\footnotetext{
${ }^{1}$ See also Manacorda, Manning, and Wadsworth (2012) for evidence that immigrants and natives might be imperfect substitutes within education/experience cells in the UK. Peri and Sparber (2009) shows that low-skill natives in local labor markets receiving more immigrant inflows tend to specialize in occupations requiring more abstract tasks in response to immigration. Dustmann et al. (2013) shows that recent immigrants start working in occupations offering a much lower wage than natives with similar observable characteristics.
} 
likely to offer skills similar to the skills of immigrants, even if they have a different education and experience level. ${ }^{2}$ By comparing homogenous groups of natives initially in the same occupation across labour markets experiencing different immigration inflows, we can investigate whether the natives more directly in contact with immigration ended up doing worse in terms of wages or employment.

Such an approach faces important theoretical and empirical challenges. In particular, the requirements in terms of data are considerable: the effect of immigration may not be limited to wages or employment, and immigration inflows may generate a reallocation of natives to other locations (Borjas, 2006) or to different occupations (Peri and Sparber, 2009). To accurately assess the full consequences of immigration on these workers, it is necessary to have data which allows us to identify their initial job but also which allows us to follow them over time in order to observe their labour market trajectory. In addition, if immigration results in the reallocation of natives across occupations or locations, the effect of immigration will not be circumscribed to particular groups of workers but instead will spread out across labour markets.

We empirically investigate these questions with a large administrative French panel that follows workers' labour market trajectories over the period 1976-2007. We focus our analysis on various groups of blue-collar native workers initially employed in industries that differ in their share of immigrants. As immigration was mainly low-educated in this period, blue-collar workers have been disproportionately affected by the large inflows of low-skill immigrants in recent decades.

The panel provides exhaustive and reliable information on the wages, occupation, number of days worked, and geographical location at the municipality level for about $4 \%$ of

\footnotetext{
${ }^{2}$ See e.g. Orrenius and Zavodny (2007) for a paper following such approach.
} 
French private sector employees. In contrast to many papers, the large size of our panel allows us to focus on quite narrowly defined groups of workers and we can also rely on very large (25\%) sample extracts from the Census to count how many low-educated immigrants arrive in each local labour markets and to construct an instrumental variable for these inflows based on ethnic networks.

Another advantage of using panel data is that we can both assess and control for changes in unobserved heterogeneity of workers within occupations. As job movers might not be randomly selected, immigration might affect how native workers are distributed by skill levels across occupations. With longitudinal data, we can isolate the causal effect of immigration on wages from any compositional change. In addition, as we track workers over time, we can directly investigate the selection patterns of those who move across occupations or locations.

To guide the empirical work, we first describe a simple Roy model à la Gibbons, Katz, Lemieux, and Parent (2005) in order to explain the selection of workers across occupations. In such a model, workers' allocation across sectors is governed by comparative advantage as returns to skills are sector specific. These comparative advantages depend on observed and unobserved individual skills. The pressure of immigration on wages in some sectors provides incentives for natives to reallocate across sectors, which in turn affects wages by changing the distribution of ability across sectors. As a result, changes in average wages in a sector caused by an immigrant inflow also reflect changes in the average ability in the group.

We examine the implications of this model with the data. We start by presenting new evidence on the reallocation of natives across locations and occupations after an immigrant inflow at the local level. Regarding geographical mobility, we find compelling evidence in alternative datasets of a positive correlation between low-educated immigrant inflows and outflows of blue-collar natives from the local labour market. Quantitatively, baseline 2SLS 


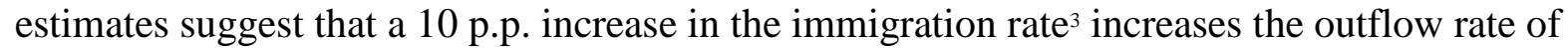
blue-collar natives by 1.8 p.p. An important new result is that these outflow rates vary dramatically with the initial occupations. In particular, we estimate twice as large displacement effects for workers in the most immigrant-intensive industries such as nontradable industries and particularly the construction sector.

Second, consistent with Peri and Sparber (2009) for the U.S. or Ortega and Verdugo (2014) for France, we find that natives are more likely to change occupation following immigrant inflows and that this change is towards better-paid occupations that require less routine tasks. However, once again, the estimated effect varies in an important way with respect to the initial occupation. In particular, we find no occupational upgrading for those with the lowest skills in the construction sector or in the non-tradable sector.

Third, there is also strong evidence that, within groups, workers changing location or occupation are not a random sample of the sending population. Specifically, those moving to occupations with less routine tasks tend to be positively selected, in the sense that they initially had higher wages in the group. In contrast, workers changing location tend to be negatively selected. As selection is positive along one dimension and negative along the other, the overall effect of selection on the average wage in the occupation is generally ambiguous.

In the second part of the paper, we assess the impact of immigration on the employment outcomes and on the wages of natives at the occupation level, devoting particular attention at assessing the extent to which compositional changes and endogenous selection affect the estimates.

\footnotetext{
${ }^{3}$ We define the immigration rate as the ratio between the number of low-educated immigrants and blue-collar natives in the commuting zone.
} 
We find no evidence of a negative impact of immigration on the number of days worked, and this result systematically holds across different subgroups of workers. No negative effect on the employment to population rate is found either.

In contrast, the results indicate that average wages fall in response to immigration, and particularly so for blue-collar natives initially employed in sectors with a large number of immigrants. Overall, we find that an increase in 10 p.p. in the immigration ratio at the local level lowers the average daily wage by 1 log point. Nevertheless, a strong heterogeneity is observed. We find much larger effects for natives initially in the non-tradable sector, and particularly so for low-skill construction workers. For this group, an increase in 10 p.p. in the immigration ratio at the local level lowers the wages by 4.2 log points.

We also obtain larger negative wage effects when the sample includes location movers, which suggests that location movers experience a larger fall in wages than stayers. In contrast, the negative effects of immigration are found to be much smaller when the sample includes occupation movers. Finally, we find that controlling for composition matters. ${ }^{4}$ Most of the times, the equivalent cross-sectional estimates -i.e. the estimates with the same data when the longitudinal dimension is not exploited-are measured much less precisely and tend be lower.

Our work contributes to a rapidly growing literature studying the impact of immigration with panel data. Most of the existing papers also find the effect of immigration on wages to be heterogeneous across groups of natives. ${ }^{5}$ However, most of these papers do not analyze how

\footnotetext{
4 This result is consistent with Bratsberg and Raaum (2012) that also found that selective attrition might mask the causal wage impact of immigration using data from the construction sector in Norway.

${ }^{5}$ De New and Zimmermann (1994) find small gains for white-collar employees but larger negative effects for blue-collar workers. Bratsberg, Raaum, Røed and Schøne (2014) find heterogeneous wage effects depending on the country of origin of immigrants. Cattaneo, Fiorio and Peri (2015) find that European workers are more likely to choose occupations associated with higher skills and status. D'Amuri and Peri (2014) show that the reallocation of natives is larger in countries with more flexible labor laws. Foged and Peri (2016) consider the geographical and cross-industry variation in the proportion of immigrants in Denmark, and show that immigration has a positive wage impact on the less skilled natives and encourages them to work in more complex occupations.
} 
immigration alters the selection of workers, and particularly so in the geographical dimension, or how immigration impacts the employment and wages of occupation or location movers. ${ }^{6}$

The remainder of the paper is organised as follows. The first section presents the data and provides some descriptive evidence on immigration into France. The second section discusses the empirical framework. The third section investigates the relationship between the selection of natives across locations and occupations, and immigrant inflows. The fourth section examines the impact of immigration on employment and wages. The last section concludes.

\section{I) Data and descriptive evidence}

\section{Data Sources}

Our primary data source is the matched employer-employee panel DADS (Déclaration Annuelle de Données Sociales) collected by the French National Institute for Statistics (INSEE). ${ }^{7}$ The sample contains earning histories for all individuals born in even-numbered years in October. The DADS panel is available annually from 1976 to 2007 except for 1981, 1983 and 1990 where the data were not collected.

Three features of this dataset make it well-suited for our purposes: first, the data are collected for compulsory fiscal declarations made annually by all employers for each worker and the data is thus considered very reliable. ${ }^{8}$ The wage data in particular are considered of very good quality, as the reporting is made by the employer and is used by the tax authorities to calculate the income tax of the worker. Employers have no incentives to misreport wages as this is severely punished with fines. Second, since the data are collected for fiscal reasons,

\footnotetext{
${ }^{6}$ A recent exception is Lull (2014) that provides an interesting evaluation of compositional changes in the native population following immigration using a structural econometric approach.

${ }^{7}$ See e.g. Abowd, Kramarz, and Margolis (1999) or Combes, Duranton, and Gobillon (2008) for recent papers using this dataset.

${ }^{8}$ Civil servants and some public sector firms are excluded until the early 1990s. Using data from the French Labor Force Survey, we estimate that they represented approximately $8 \%$ of the labor force during the period.
} 
involuntary attrition has been evaluated to be very low and mostly corresponds to the absence of any work during a year. ${ }^{9}$ Third, the sampling size is very large: we have information on 350,000 individuals per year over the period, amounting to about $4 \%$ of private sector employees. ${ }^{10}$

The data contain a unique record for each employee-establishment-year combination. For each job spell, the panel reports earnings, whether the job was part-time or full-time, the number of days of work and the location at the municipality level. ${ }^{11}$ We aggregate job spells over the year to obtain the total annual labour earnings and total annual number of days worked for each individual. Whenever an individual has worked in several occupations or industries in a given year, the individual is allocated to the occupation/industry of the job held for a longer period of time. A shortcoming of the data is that it does not include information on education. In addition, as the DADS does not supply any detailed information on the nationality of the respondent but reports instead whether the individual is born in France or not, natives are defined as those individuals born in France. ${ }^{12}$

The number of immigrants across labour markets is measured with Census data. We do so for two reasons. First, we have access to $25 \%$ extracts of the population (20\% in 1975), which renders our estimates immune from attenuation biases as identified in Aydemir and Borjas (2011), and even so in small labour markets. Second, unlike the DADS, the Census includes information on the country of origin of immigrants which allows us to construct an

\footnotetext{
${ }^{9}$ Koubi and Roux (2004) documents that most of the temporary attrition from the DADS panel corresponds in practice to inactivity or to working outside of the DADS-covered sector (such as self-employment, or a job in the public sector). Attrition in the DADS panel has also been shown to be negligible compared with typical survey-based panels such as the European Community Household Panel (Royer, 2007).

${ }^{10}$ The sampling size doubles in 2002 when individuals born in odd-numbered years in October are added to the sample.

${ }^{11}$ Information on whether an employment spell was full or part time is available over the entire period but the number of hours worked is only available after 1993 (see Aeberhardt, Givord, and Marbot, 2012, for a discussion). Following the current practice, as the number of hours is quite noisy, we have chosen not to use it.

${ }^{12}$ All individuals born in Algeria before its independence from France in 1962 are reported in the DADS as being born abroad independently on whether they are of European or Arab origin. For this reason, Europeans born in pre-independence Algeria cannot be counted as natives. From the Census, we estimate that the share of European Algerians among 18-65 years old natives is 2.2\% in 1982 and 1\% in 2007. More generally, the share among natives of French-born citizens who are born abroad is rather small and declining over time: $4.4 \%$ and $3.2 \%$ in respectively 1982 and 2007 .
} 
instrumental variable for the location choices of immigrants based on differences in the initial settlement patterns across immigrant groups.

Censuses of the population took place in 1968, 1975, 1982, 1990, 1999 and 2007. As is conventional, an immigrant is defined as a foreign-born individual who is a non-citizen or naturalised French citizen. We focus on low-educated immigrants with a level of education below high-school graduation.

Local labour markets are defined using the 2010 definition of commuting zones (zones d'emploi) designed by the French Statistical Institute. Commuting zones approximate local labour markets using information on daily commuting patterns. They aggregate the 36,699 French municipalities into 297 labour market regions. ${ }^{13}$

Our empirical study covers the period from 1975 to 2007 . We combine information on the employment and wages of natives from the DADS panel with data on the number of loweducated immigrants at the commuting-zone level obtained from the Census. We only retain years in the sample when both datasets are available. This implies that our regressions exploit medium-run variations in immigration and labour market outcomes over periods of 7 to 9 years. ${ }^{14}$

As the DADS data does not contain information for individuals with no labour earnings during a complete year, we are concerned that selective attrition to non-employment might bias our results. To minimise these risks, we restrict the sample to male workers aged 25-54. This subgroup of workers have a relatively strong labour market attachment and thus nonemployment during a full year is less likely to be a major issue. ${ }^{15} \mathrm{We}$ focus on changes in

\footnotetext{
13 Commuting zones are defined in a consistent way over time using the municipality identifier. We drop commuting zones from Corsica (less than $0.3 \%$ of the population), as a change in the département code in 1976 complicates their matching across datasets over time. Commuting zones have been previously used with the DADS panel in Combes et al. (2008) and Combes, Duranton, Gobillon, and Roux (2012).

14 Given DADS data were not collected in 1975 and 1990, we match Census data from 1975 and 1990 with the DADS data from respectively 1976 and 1991.

15 We also apply these restrictions to avoid issues with changes in retirement age over time. Young workers are also eliminated to avoid problems with potentially endogenous labor market participation in case immigration influences educational decisions (Hunt, 2016). Unfortunately, by doing so, we potentially ignore the quite large impact of immigration on the youth labor market (Smith, 2012).
} 
outcomes across Census years of workers initially aged 25 to 45 in census year $t$ and 32 to 52 or 34 to 54 in census year $t+1$.

\section{Immigration in France: Key Figures}

In 2007, 5.2 million immigrants lived in France, amounting to $8.3 \%$ of the population, a smaller proportion than in the US or the UK (respectively $11.5 \%$ and $11.9 \%$, see Dustmann et al., 2013, p. 11). Over the last decades, as in most European countries, the geographical origin of immigrants dramatically changed with the share of European immigrants among immigrants falling from about $60 \%$ in 1975 to only $32 \%$ in 2007 . At the same time, the average educational level of immigrants relative to natives fell during this period, which reflects both a higher educational attainment of natives (Verdugo, 2014) and a lower educational level of non-European immigrants (mostly below secondary school completion). As a result, the share of immigrants among low-skilled workers rapidly increased.

Specifically, from 1975 to 2007, the share of immigrants among male workers with less than high-school education increased by 5 p.p. from $13 \%$ in 1975 to $18 \%$ in $2007 .{ }^{16}$ This paper exploits this substantial increase and its local variations to identify the impact of immigration.

As in most developed countries, low-educated immigrants are concentrated in specific occupations and regions. Table 1 reports the proportion of foreign born among blue-collar workers in 1999 in the tradable and non-tradable sectors. ${ }^{17}$ Relative to the tradable sector, the share of foreign born workers in the non-tradable and the construction sector is higher by respectively 4 p.p. and 10 p.p. Across regions, many immigrants are located in large cities in the North, the East and the South while they remain rare in the West and the Centre of France. For instance (see Table 2), in 1999, foreign-born construction workers amounted to $5 \%$ of the

\footnotetext{
${ }^{16}$ Unless otherwise indicated, figures in this section are for male workers aged 18-64 who are not students or in the military.

${ }^{17}$ We rely on standard classification systems of industries. See Appendix for details on industries and occupation classifications used in the paper. Following Hanson and Slaughter (2002) and Dustmann and Glitz (2015), the group of tradable industries includes manufacturing, agriculture, mining, finance and real estate.
} 
construction workers in Brittany but instead $45 \%$ of the construction workers in Paris.

However, in both regions, the share of foreign-born workers in this sector grew in the last 30 years.

\section{II) Conceptual Framework}

To set the stage for the empirical analysis, we describe a simple extension of a Roy model à la Gibbons et al. (2005) where comparative advantage determines the allocation of workers in a multi-sector economy. As the model is quite general, it can also be extended to analyse residential mobility, as a "sector" can be interpreted as a different location. ${ }^{18}$ The model provides a conceptual framework to interpret how the selection patterns of movers depends on their initial sector and on their position in the skill distribution. The model also illustrates how the reallocation of workers affects wages in other sectors even when immigrants concentrate in only one sector. ${ }^{19}$

Assume the production function in sector $k$ at period $t$ can be written as $Y_{k t}=A_{k t} L_{k t}^{1-\sigma}$ where $Y_{k t}$ is output, $L_{k t}$ is the total quantity of labour in the sector, $A_{k t}$ is total labour productivity, and $0<\sigma<1$. As in Combes et al. (2008), workers are perfect substitutes but heterogeneous in the number of efficiency units of labour $s_{i k t}$ they supply. As a result, the aggregate amount of labour in sector $k$ is given by $L_{k t}=\sum_{i \in J_{k}} s_{i k t} l_{i t}$ where $J_{k}$ is the set of workers supplying labour in sector $k$.

We follow Gibbons et al. (2005) by assuming that sectors differ in their returns to observed and unobserved characteristics, which generates the sorting of workers across

\footnotetext{
18 Selection related to locational migration can also be generated by heterogeneous moving costs of workers across locations as in Moretti (2011) or Beaudry, Doms, and Lewis (2010). See also Borjas (2006) for a model where immigration influences the location choices of natives.

19 The model focuses on selection and reallocation and neglects the role of capital adjustment (Dustmann et al., 2013) or the existence of imperfect substitution between natives and immigrants (Ottaviano and Peri, 2012, Manacorda et al. 2012).
} 
sectors. Specifically, we assume that the efficiency units of labour of a type- $i$ worker $\left(s_{i k t}\right)$ can be decomposed as $\log s_{i k t}=X_{i t} \phi_{k}+\eta_{k} \alpha_{i}$, where $X_{i t}$ is a vector of time-varying observed characteristics of the worker and $\alpha_{i}$ is the worker's fixed effect unobserved productivity. The terms $\phi_{k}$ and $\eta_{k}$ capture occupational specific returns to respectively observed and unobserved worker characteristics. For simplicity, a higher index $k$ is assigned to an occupation the higher the return to unobserved ability $\eta_{k}>0$ within the occupation.

With competitive labour markets, the log wage $w_{i k t}$ of worker $i$ in sector $k$ in period $t$ is given by the log marginal product of labour:

$$
w_{i k t}=B_{k t}-\sigma \log L_{k t}+\eta_{k} \alpha_{i}+X_{i t} \phi_{k}
$$

where $B_{k t}=\log \left((1-\sigma) A_{k t} p_{k t}\right)$ and $p_{k t}$ is the price of the sector- $k$ good.

Given that the payoffs to ability are sector specific, workers will not be initially indifferent across sectors and in the absence of mobility costs simply choose the sector offering the highest wage given their skills. Conditional on $X_{i t}$, the equilibrium is thus characterised by a set of thresholds denoted $v_{k}\left(X_{i t}\right)$ and an allocation of workers across sectors $\left(L_{1, T}^{*}, \ldots, L_{K, T}^{*}\right)$ such that no worker gains by moving to another sector. Thus, individuals choosing to work in sector $k$ are such that their unobserved ability satisfies $v_{k-1}\left(X_{i t}\right)<\alpha_{i}<v_{k}\left(X_{i t}\right)$. Analytically, we get: ${ }^{20}$

$$
v_{k-1}=\frac{B_{k-1, t}-B_{k, t}-\sigma\left(\log L_{k-1, t}^{*}-\log L_{k, t}^{*}\right)+X_{i t}\left(\phi_{k-1}-\phi_{k}\right)}{\eta_{k}-\eta_{k-1}},
$$

which shows that an exogenous increase in labour supply in any sector $k$ (i.e. a shock to $L_{k, t}$ ) impacts the allocation of workers across sectors through adjustments in relative wages.

\footnotetext{
${ }^{20}$ We assume that $B_{k, t}-\sigma \log L_{k t}>B_{k+1, t}-\sigma \log L_{k+1, t}$ holds for all $k$, a necessary condition for workers to be present in all sectors.
} 
Firms can employ natives $N_{k t}$ or immigrants $I_{k t}$, i.e. $L_{k t}=N_{k t}+I_{k t}$. Consider now an inflow of immigrants $\Delta I_{k, t}$ into sector $k$ and assume as in Borjas (2003) that immigrants are not mobile across sectors. Before any reallocation of natives across sectors has taken place, from (2) the immigration inflow reduces the threshold by $\Delta v_{k-1}=\frac{\sigma}{\eta_{k}-\eta_{k-1}} \frac{\Delta I_{k, t}}{N_{k, l t}}$ and the natives with the highest unobserved productivity in sector $k-1$ move to sector $k$. Similarly, $\Delta v_{k}=\frac{-\sigma}{\eta_{k+1}-\eta_{k}} \frac{\Delta I_{k, t}}{N_{k, l t}}$, and the sector- $k$ most productive natives move to sector $k+1$.

To illustrate this, Figure 1 represents a three-sector economy characterised by higher returns to unobserved ability in sector 3 than in sector 2 , and in turn in sector 2 than in sector 1 . Initially, individuals with $\alpha_{i}<v_{1}\left(X_{i t}\right)$ choose sector 1 , while those with $v_{1}\left(X_{i t}\right)<\alpha_{i}<v_{2}\left(X_{i t}\right)$ and $\alpha_{i}>v_{2}\left(X_{i t}\right)$ choose respectively sector 2 and sector 3 . Consider now an exogenous immigration inflow into sector 2 , which results in a fall in the sector- 2 wage schedule from $w_{i 2 t}\left(\alpha_{i}\right)$ to $w_{i 2 t}{ }^{\prime}\left(\alpha_{i}\right)$ and initially pushes workers with unobserved ability $v_{1}\left(X_{i t}\right)<\alpha_{i}<v_{1}^{\prime}\left(X_{i t}\right)$ away from sector 1 and into sector 2, and workers with unobserved ability $v_{2}^{\prime}\left(X_{i t}\right)<\alpha_{i}<v_{2}\left(X_{i t}\right)$ away from sector 2 and into sector 3 . However, this is not the full story as this reallocation of natives will drive down wages both in sector 1 and in sector 3 , and in addition raise (resp. lower) the average ability in sector 1 (resp. sector 3). Graphically, the wage schedule in sectors 1 and 3 will move down, while the schedule in sector 2 moves up, until a new equilibrium is reached. 


\section{Figure 1: Effect of Immigration on Workers assignment with Comparative Advantages}

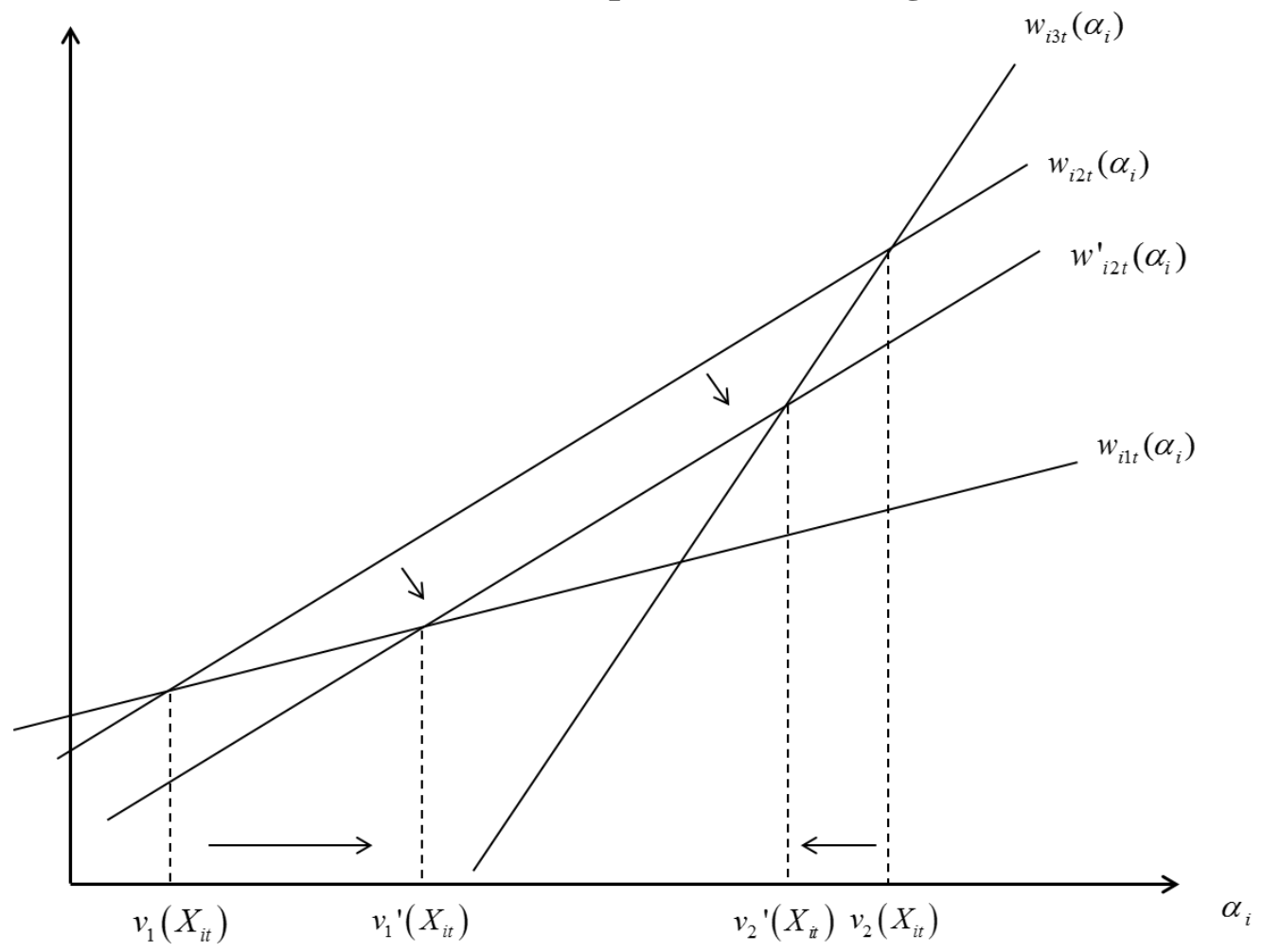

The estimation of the effect of immigration on wages is complicated by these endogenous reallocations. As noted before, the model predicts that workers changing occupation are not a random sample of the initial group. Depending on whether their destination is a sector with higher or lower returns to skills, they originate from either the bottom or the top of the distribution (conditional on $X_{i t}$ ). At the same time, this changes the composition of workers across sectors and attenuates the initial effect of immigration in a sector.

From (1), computing the difference of the average occupation- $k$ log wages $\overline{w_{k t}}$ in between periods $t$ and $t-1$, we get:

$$
\Delta \overline{w_{k t}} \equiv \bar{w}_{k, t}-\bar{w}_{k, t-1}=\Delta B_{k t}-\sigma \log \frac{L_{k t}}{L_{k, t-1}}+\phi_{k} \Delta \bar{X}_{k t}+\eta_{k}\left(\bar{\alpha}_{k, t}-\bar{\alpha}_{k, t-1}\right)
$$

where $\bar{X}_{k t}$ and $\bar{\alpha}_{k, t}$ are respectively the average observable and unobservable individual characteristic in the occupation. Assuming for simplicity that there are no immigrants in 
period $t-1$ in the occupation i.e. $L_{k, t-1}=N_{k, t-1}$, defining $e_{k t}$ such that $N_{k, t}=N_{k, t-1}-e_{k t} \Delta I_{k, t}$, we get that $\log \left(\frac{L_{k, t}}{L_{k, t-1}}\right)=\log \left(1+\frac{\left(1-e_{k t}\right) \Delta I_{k, t}}{N_{k, t-1}}\right) \simeq \frac{\left(1-e_{k t}\right) \Delta I_{k, t}}{N_{k, t-1}}$. Replacing this expression into (3), we get:

$\Delta \overline{w_{k t}} \equiv \bar{w}_{k, t}-\bar{w}_{k, t-1}=\Delta B_{k t}-\sigma \frac{\left(1-e_{k t}\right) \Delta I_{k, t}}{N_{k, t-1}}+\phi_{k} \Delta \bar{X}_{k t}+\eta_{k}\left(\bar{\alpha}_{k, t}-\bar{\alpha}_{k, t-1}\right)$

The term $\bar{\alpha}_{k, t}-\bar{\alpha}_{k, t-1}$ captures changes in the unobserved productivity of workers in occupation group $k$ and will generally be different from zero. The direction of the biases related with these unobserved changes in average ability is uncertain as movements from both low- and high-skill workers are possible. The bias also depends on $\eta_{k}$, which determines the returns to specific skills in the sector.

Another interesting implication of the model is that the wage loss related with immigration depends on whether an individual changes occupation or not. For those changing occupation, the wage loss depends on the ability level $\alpha_{i}$ and differences in returns to ability across sectors $\eta_{k}$.

\section{III) Empirical Implementation}

To take the previous model to the data, we adopt a local labour market approach and use differences in immigrant inflows across local labour markets to identify the model. Assuming, as common in the literature, that $\Delta B_{k t}$ in (4) can be captured by a full set of time $\left(\gamma_{k t}\right)$ and regional $\left(\gamma_{k r}\right)$ fixed effects, equation (4) leads to a regression model of the type

$$
\Delta y_{k l t}=\beta_{k} \Delta p_{l t}+v_{k} \Delta Z_{l t}+\phi_{k} \Delta X_{k l t}+\gamma_{k t}+\gamma_{k r}+\varepsilon_{k l t}
$$

where $\Delta y_{k l t}$ is the change in a given outcome between two periods for occupational group $k$ in location $l, Z_{l t}$ is a vector of locational industry-specific factors varying over time and 
contains several location and industry specific factors varying over time and $\Delta p_{l t}=\frac{I_{l t}-I_{l t-1}}{N_{l, t-1}}$ is the change in the number of low educated immigrants relative to the initial number of native blue-collar workers in the location. Note that following recent work by Dustmann et al. (2013) among others, we do not assign low-educated immigrants to a particular sector $k$ and thus the term $\Delta p_{l t}$ is not specific to the occupation. ${ }^{21}$ In practice, it would be difficult to find an instrument if we had assigned immigrants to a particular sector. The use of a similar numerator across occupation groups also facilitates the interpretation and the comparison of the results across groups.

The model is estimated by pooling multiple decades across censuses as stacked first differences. Differencing eliminates time-invariant observed or unobserved wage differences across occupation groups and locations that could be correlated with low-skilled immigration. The specification also includes changes in average individual-level demographic controls $\left(X_{k l t}\right)$ and changes in area level controls as well $\left(Z_{k l t}\right)$. We include the average experience, changes in the share of white- to blue-collar workers, the share of workers in construction, the overall share of workers in manufacturing industries and the average age of workers. As in Dustmann and Glitz (2015) or Smith (2012), regressions are weighted by the number of observations used to compute the dependent variable. Specifically, firstdifferenced equations are weighted by $\left(1 / N_{k l t}+1 / N_{k l t-1}\right)^{-1 / 2}$ where $N_{k l t}$ is the number of workers in the cell..$^{22}$

\footnotetext{
21 This approach is also followed by Smith (2012), Card (2001), Card and DiNardo (2000), or Mazzolari and Neumark (2012) among others.

22 This expression is derived from straightforward calculations of the variance of a first-difference variable measured with errors when the measurement error is proportional to the number of observations and is independent across years.
} 


\section{Groups'Definition}

Our approach is to test for potential heterogeneity in the response to immigration by considering increasingly homogenous groups of blue-collar workers in specific industries or with specific skill levels. The large size of our data guarantees that we have enough observations even for quite narrowly defined groups. In addition, because we use administrative data, measurement errors in wages are also minimised.

In addition to considering blue-collar workers as a whole, we study different subsets of this group such as the blue-collar workers employed in tradable or non-tradable industries. In turn, within the non-tradable industries, we consider also in isolation the blue-collar workers employed in the construction sector, the non-tradable industry with the largest share of immigrants. We also distinguish blue-collar workers by their skill level, and as immigrants are more likely to be employed in unskilled blue-collar jobs, ${ }^{23}$ we consider two other groups restricted to the less-skilled blue-collar workers in the non-tradable sector and in the construction sector.

A comparison of separate estimates across groups will indicate whether the impact of low-skilled immigration significantly differs across blue-collar workers with different levels of skills and employed in different sectors. If labour markets are segmented, the supply effect of immigration should vary across workers. On the other hand, if blue-collar workers are close to perfect substitutes, then the impact of immigration should be similar across groups.

\section{Identification: accounting for composition effects and endogenous immigrant}

\section{location choices}

Equation (4) makes it clear that changes in average wages within groups reflect both the impact of immigration on the supply of labour and endogenous changes in the unobserved

\footnotetext{
${ }^{23}$ In the French occupational classification, skilled blue-collar workers (ouvriers qualifiés) include machine operators, mechanics or more generally tradesman while unskilled blue-collar (ouvriers non-qualifiés) typically refers to laborers.
} 
average productivity of workers. Panel data allows us to control directly for changes in unobserved heterogeneity within groups. The most straightforward way to do this, as we can follow workers over time, is to perform our estimates on a balanced panel that keeps the composition of the sample constant across periods. Using this simple method, we can also assess how composition effects affect the estimates by comparing results obtained from a balanced panel with estimates using variations from cross-sectional data.

Unlike most previous work, we define groups of workers based on their initial instead of their contemporary occupation. As a result, we estimate models including all natives initially in a given occupation and location, instead of restricting ourselves to the natives that remained on both periods in the same occupation and location. By including the movers in the sample, we take into account the effect of immigration on those who might have endogenously left the occupation. To assess how much movers gain or lose with respect to stayers, we compare estimates for all workers with estimates restricted to those who stayed.

A second important issue is that it is very unlikely that immigrants' geographic settlement decisions are exogenous to local labour market conditions. If immigrants settle disproportionately in areas with better local labour market, then ordinary least squares (OLS) estimates will be biased.

Following other studies that use a local labour markets approach, we construct an instrumental variable to deal with this issue. As in Card (2001) and Cortes (2008), we use the initial proportion of co-nationals in the commuting zone to construct an instrument for future immigrant inflows. Specifically, the predicted number immigrants from country $c$ in location 1 is simply given by the total number of immigrants $I_{c t}$ from that country in the Census year $t$ multiplied by the proportion of those immigrants (both skilled and unskilled) that were 
choosing that location in the previous census $t$-1, i.e. $\lambda_{c l, t-1}=\frac{I_{c l, t-1}}{I_{c, t-1}}$. Adding up across countries of origin, the expected number of immigrants in location $l$ is then given by

$$
\hat{I}_{l t}=\sum_{c} \lambda_{c l, t-1} I_{c t}
$$

Given the large sample size, we can exploit the 54 different countries of birth available in the data. Following Hunt and Gauthier-Loiselle (2010), the local share of immigrants $\lambda_{c l, t-1}$ is estimated using immigrants from all education and experience levels as local ethnic networks are likely to include individuals with different characteristics. Because the endogenous variable is a percentage, our final instrument $\Delta \hat{p}_{l t}$ is defined by using changes in the number of predicted immigrants in the location divided by the initial number of natives, i.e. $\Delta \hat{p}_{l t}=\frac{\hat{I}_{l t}-\hat{I}_{l t-1}}{N_{l t-1}}$.

Table 3 examines how well this instrument predicts changes in the immigrant ratio. Observations correspond to first-differences between census years (i.e., 1975-1981, 19811990, 1990-1999, and 1999-2007) for each of the 297 commuting zones. Column (1) reports estimates from a simple bivariate model while column (2) includes a full set of control variables. In both specifications, the coefficient is positive and strongly significant. A comparison between columns (1) and (2) indicates that including the control variables in the model lowers by a third the estimated parameter but also raises the precision of the estimate. With unweighted estimates (column 3), the coefficient diminishes slightly but still remains statistically significant. The F-statistics ${ }^{24}$ are close to or greater than 30 in all cases, thus easily passing the weak instrument test.

\footnotetext{
${ }^{24}$ As we use cluster robust standard errors at the commuting zone level in our regression, we report the Kleibergen-Paap F-stat.
} 


\section{IV) Immigrant Inflows and Natives' Mobility Patterns}

Before looking at standard measures of the labour market impact of immigration such as wages and employment, we first assess the relevance of mobility across locations and occupations as adjustment channels to immigration.

\section{Geographic mobility}

We begin with the relationship between local immigrant inflows and native outflows from the commuting zone, currently the focus of a growing literature. ${ }^{25}$ Following Card $(2001,2009)$ or Cortes (2008), we use as a dependent variable the outflow rate defined as $O_{k l t} / N_{k l t-1}$, where $O_{k l t}$ is the number of natives from occupation $k$ that were in location $l$ in Census $t-1$ and have moved to a different location by Census $t$. We regress these outflow rates on changes in the share of low-educated immigrants in the corresponding period as in Eq. (5).

Table 4 shows the results. The first column reports results for all natives who are bluecollar workers in the initial period while the other columns report estimates performed on increasingly homogenous groups of workers. Both OLS and 2SLS results suggest that bluecollar natives respond to immigrant inflows by changing location. Strikingly, IV estimates are much larger than OLS estimates. Specifically, the coefficients indicate that an increase of 10 p.p. in the immigration rate raises the outflow rate by 2.1 p.p. for natives in the nontradable sector and by 4.0 p.p. for low-skill natives in the construction sector. These effects are non-negligible as they correspond to a 10 to 20 percent increase of the baseline outflow rate in our sample. We also find important differences across groups, as outflows tend to be much larger in the non-tradable sectors and particularly so in the construction sector.

\footnotetext{
${ }^{25}$ Using US decennial data, Card (2001) and Cortes (2008) have found no evidence of native outflows in response to immigrant inflows while Borjas (2006), on the other hand, reports strong displacement effects. More recently, using US annual aggregate data, Wozniak and Murray (2012) find that immigrant inflows are correlated with declines in outflows of low skill natives within a period of one year. Recent European studies found stronger evidence of displacement following immigration inflows (see Hatton and Tani, 2005, for consistently negative displacement effects in the UK, and Mocetti and Porello, 2010, for evidence of displacement of low-skill natives in Italy).
} 
As noted before, if mobility is observed, an important question is whether movers and stayers have different characteristics, as this would imply that mobility changes the composition of natives across locations and occupations. Our simple sorting model predicts that if the destination sector is characterised by higher (resp. lower) returns to skills, movers should be more (resp. less) skilled than stayers.

While different criteria are possible, we adopt a simple approach to study selection by considering the initial location in the wage distribution in the group. Following Borjas (1999), we define positive selection as a situation where, conditional on the occupation and location:

$$
E\left(\log w_{i k l t-1} \mid \text { movers in } \mathrm{t}\right)>E\left(\log w_{i k l t-1} \mid \text { stayers in } \mathrm{t}\right)
$$

where $w_{i k t-1}$ is the initial wage level. If there is positive (resp. negative) selection, emigrants have on average higher (resp. lower) wages than non-migrants in the initial location. We test for selection with the following specification estimated at the individual level:

$$
\text { Move }_{i k l t}=\Gamma_{k}^{1} \tilde{w}_{i k l t-1}+\Gamma_{k}^{2}\left(\tilde{w}_{i k l t-1} \times \Delta p_{l t}\right)+\beta_{k} \Delta p_{l t}+v_{k} \Delta Z_{l t}+\phi_{k} \Delta X_{k l t}+\gamma_{k t}+\gamma_{k r}+\varepsilon_{k l t}
$$

where the dependent variable Move $_{i k l t}$ takes the value 1 if the individual $i$ has left the location in period $t+1$ and the variable $\tilde{w}_{i k l t-1}=w_{i k l t-1}-\bar{w}_{k l t-1}$ is the deviation from the average wage in the cell.

In this specification, while $\beta_{k}$ that captures the effect of immigration on mobility, the parameters $\Gamma_{k}^{1}$ and $\Gamma_{k}^{2}$ test for the selection of movers. The first coefficient indicates how the wages of movers compares to the wages of stayers. The second coefficient tests if the selection patterns vary with immigrant inflows. Estimation relies on 2SLS using the 
previously described instrument for $\Delta p_{l t}$ and the interaction of this instrument with the wage as the interaction term $\left(\tilde{w}_{i k l t-1} \times \Delta p_{l t}\right) \cdot{ }^{26}$

Table 5 provides the results. Within each panel, column 1 and 2 compare the estimates from the baseline model obtained with aggregate and individual level data, respectively. Reassuringly, we observe little difference between the two estimates. Column 3 introduces the initial wage. For all occupation groups, the results paint a consistent picture: workers that are more likely to leave the location tend to have lower wages with respect to the initial group. We find that an increase of one standard deviation of the initial wage (about 0.32) decreases the probability to change location by 3.9 p.p. $(0.32 \times 0.122)$. Column 4 tests whether the selection pattern varies with immigrant inflows. For most groups, the interaction term is very small and statistically insignificant. Overall, there is little evidence that the selection varies with the share of immigrants.

As noted before, the DADS panel only contains individuals with a positive number of hours worked in a year. Even if we focus on male aged 25-55 to minimise this risk, selective attrition to nonparticipation during a full year could still bias our estimates. To assess the robustness of our results, we use alternative outflows rates that can be estimated with the Census and covering the entire population. ${ }^{27}$ As no information on initial occupations is available in the data, we classify workers according to their educational attainment (primary, secondary, high-school, or university graduates). ${ }^{28}$

The results in Table 6 are consistent with previous evidence, as the 2SLS estimates indicate that an increase by 10 p.p. in the immigration rate raises by 2.5 p.p. and 2.8 p.p. the

\footnotetext{
${ }^{26}$ To account for the fact that $\Delta p_{l t}$ does not vary at the individual level, we use standard errors clustered at the location by year level in this specification.

${ }^{27}$ Outflows rates can be calculated using retrospective information on the location during the previous census. This information is available at the municipality level.

${ }^{28}$ See the Appendix for details on the construction of these education groups. Note that selection patterns cannot be evaluated from Census data, as wages are not reported.
} 
outflow rate of natives with respectively primary and secondary education. In contrast, no statistically significant correlation is found for more educated workers. Overall, Census data tend thus to confirm our previous results with DADS data and give us little reason to believe that attrition significantly biases DADS results.

\section{Occupational Mobility}

A second type of adjustment often emphasised in the literature is that natives might move to a different occupation in response to increased competition with immigrants. Next, we examine the evidence for this type of mobility and assess its possible implications by studying the characteristics of movers.

We consider in turn different definitions of occupational change and start by defining occupational mobility as the shift from being reported as a blue-collar worker in period $t-1$ to not being anymore in period $t$. When the group definition includes the industry affiliation, we define alternatively mobility as moving to a different group of industries, even if the worker may still be in a blue-collar occupation.

Panel A in Table 7 shows that low skilled immigration is correlated with a higher probability to change occupation for blue-collar natives. The effects are quite large and have about the same magnitude than the probability to change location: 2SLS estimates in the first column indicate that an increase by 10 p.p. of the immigrant rate is associated with a 2 p.p. increase of the probability of not being in a blue-collar job in the following period. At the same time, there are substantial differences across groups and in particular no evidence of an effect when the sample is restricted to low-skilled blue-collar workers.

In Panels B, C and D, we investigate the leavers' destination occupation using as a dependent variable the probability to become respectively an employee, a technician, or a manager. Overall, there is a positive correlation between immigration and blue-collar workers upgrading their occupation to become an employee, a technician or a manager. At the same 
time, no significant effect is found when the sample is restricted to the construction sector, in particular for those with the lowest skill levels.

Another approach in the recent literature has been to measure changes in the characteristics of the occupations of natives through their task contents. Tasks performed in an occupation capture the basic skills required in a particular job (Autor. Levy, and Murnane, 2003; Acemoglu and Autor, 2011; Goos and Manning, 2007). ${ }^{29}$ As natives might have a comparative advantage in language and abstract reasoning, they might move to occupations requiring more intensively these tasks, while immigrants might concentrate, at least initially, in routine tasks that require less communication and verbal interaction. In Table 8, we follow Peri and Sparber (2009) and measure the routine intensity of an occupation by the average routine intensity of the jobs performed by the individuals employed in that occupation. ${ }^{30}$ To interpret the parameter estimates, we normalise our routine to abstract intensity index to have a standard deviation of one across occupations.

OLS estimates in panel A indicate small coefficients, either positive or negative, but which are statistically insignificant most of the times. In contrast, 2SLS estimates show clear evidence of a decrease in average routine intensity for blue-collar workers in the tradable and non-tradable sector in response to low skill immigrant inflows. The results nevertheless point, once again, to significant heterogeneities, with the coefficient being twice as small in the nontradable sector. In addition, there is virtually no evidence of an effect on the task contents of workers in the construction sector.

An interesting question is whether the previously observed decrease in routine intensity reflects a change in the quality of jobs performed by blue-collar workers or a move

\footnotetext{
${ }^{29}$ In our case, these measures are available for 7 sub-categories of blue-collar workers (ex: laborers, machine operators ...) and also for 14 other categories (managers, service workers, clerks ...).

${ }^{30}$ Routine tasks require repetitive strength and motion and non-complex cognitive skills and thus do not require good language skills. Data on task intensity come from the abstract and routine task intensity indexes calculated by Goos, Manning and Solomons (2010, Table 4 p. 49) from the Occupational Information Network (ONET) database that we have matched manually with French occupations classifications. See Appendix for details.
} 
to a non-blue-collar occupation such as technician, employee or manager. Among blue-collar workers, some noticeable variations in routine intensity are observed in the data. For example, the lowest routine intensity is reported for "laborer" with an index of 0.51 while "machine operators" have the highest index with a value of 1.30. To investigate this issue, panel B2 in Table 5 provides regressions using cross-sectional variations at the occupation group level as a dependent variable. With the exception of the tradable sectors, the coefficients are small and not statistically significant for most groups. This suggests that most of the reduction in routine intensity observed in the balanced sample is driven by workers moving out of the blue-collar category.

As previously, we document in Table 9 the selection patterns associated with these changes in task contents. Overall, we find that individuals moving to occupations with less routine tasks are positively selected. Across occupation groups, we estimate a negative coefficient of the initial wage suggesting that individuals with higher initial wages are more likely to move to occupation with lower routine intensity during the period. As for residential mobility, the interaction term is not statistically significant: there is no evidence that the selection pattern varies for different levels of immigrant inflows. In contrast, for other groups of workers, immigration is associated to occupational upgrading out of the blue-collar worker category and/or towards occupations with a lower routine component.

In sum, the results presented in this section suggest that changes in locations and occupations are endogenously related to immigrant inflows. However, the response of natives widely differs across narrowly defined groups of blue-collar workers. Importantly, there is no evidence of occupational upgrading for workers in the construction sector and for low-skill workers in the non-tradable sector. On the other hand, these workers are more likely to leave the location in response to immigrant inflows. 
An important implication of these results is that the attenuation related to endogenous response varies across groups. The fact that those leaving the location have lower wages implies that the average wages of those who stay might artificially increase by composition effects. The opposite is true for occupational mobility since those who leave tend to have higher wages than those who stay. These endogenous reallocations will bias in opposite directions cross-sectional measures of the impact of immigration on the wages of natives in these occupations. We explore this issue in the next section.

\section{V) Adjustments through Employment and Wages}

We now turn to the analysis of the impact of immigration on the wages and employment of natives, using as previously the initial occupation and local labour market as our unit of analysis. The starting point of this section is the previous finding that immigration affects the selection of workers, leading to compositional changes within occupations.

We deal with composition effects and endogenous selection by estimating the model on two balanced samples: first, we consider a sample including all the natives initially belonging to the group independently on whether or not they have changed occupation/location in the second period. By including movers, the overall impact of immigration on those initially in the occupation/location is unaffected by the selection bias related with endogenous selection across occupations/locations in response the inflows of immigrants.

To capture changes in wages within occupations net of composition effects, we estimate a second model restricting the sample to those remaining in the same occupation and location in both periods that we call the 'balanced sample of stayers'. The differences between these two balanced samples depend on the share of movers in the group and their relative wage gains or losses with respect to stayers. 
Finally, to test the extent to which composition effects bias --if neglected- the estimates of the impact of immigration on wages, a third model is estimated using crosssectional variations in the data. Workers in the cross-section sample in the initial period are the same than in the balanced sample. However, cross-sectional variations at the occupational level also reflect changes in the composition of workers as some workers leave or join the occupations. ${ }^{31}$

\section{Effects on the number of days worked}

Before focusing on wages, it is important to know whether immigration has an effect on the labour supply or the employment probability of natives. We start by estimating the effect of immigration on the number of days worked, using as a dependent variable changes in the average log of annual days of work. In panel A of Table 10, the sample includes all workers initially in the occupation while, in panel B, the sample is restricted to stayers that remained in the same occupation/location in both periods.

For both samples, we find little evidence that the share of low-educated migrants affects the number of days worked. The coefficients of 2SLS models vary in sign depending on the group under consideration but are small and generally statistically insignificant. Similarly, Panel C reports that the 2SLS estimates for the cross sectional sample are all statistically insignificant.

A potential risk for the validity of these results is attrition. Because we use administrative data, we consider involuntary attrition to be very small. However, as individuals supplying zero days of work in a year are excluded from the DADS sample, we cannot distinguish involuntary attrition from non-participation during a full year. Panel A in Table 11 reconsiders the analysis for the balanced sample including location and/or

\footnotetext{
${ }^{31}$ To keep the results comparable, as in the balanced sample, we also focus on the observed change in outcomes for workers aged $25-45$ in the initial period and 35-55 in the end period.
} 
occupation movers by assuming that any individual who is not observed in the second period has chosen to leave the labour force, i.e. by imputing zero days of work to any of these individuals. Even assuming that this extreme assumption is valid, we still do not find any negative and significant correlation between immigration and days worked. If anything, 2SLS models indicate a positive correlation for blue-collar workers, which is inconsistent with the hypothesis that immigration might decrease the labour supply of natives.

Another way of assessing the employment effect of immigration is to use Census data, which contains labour force status. To probe the robustness of our results, Panel B in Table 11 reports estimates of the impact of immigration on the employment to population rate as estimated with Census data. As in the previous section, we define groups by educational level, as we have no information on the initial occupation of workers..$^{32}$ Results are consistent with our previous analysis: immigration does not appear to be correlated with a decline in employment for prime-age male workers from different education groups. Parameter estimates are always small, and most of the time statistically insignificant. ${ }^{33}$

In sum, these different estimates paint a consistent picture. There is no evidence of an effect of immigration on the number of days worked or on the labour force status of native workers in our sample.

\section{Effects on wages}

We next estimate the effects of immigration on wages. We start in Table 12 by using as a dependent variable the changes in the average of log daily wages in the occupation group. In Panel A, that includes workers who have changed location and/or occupation in the sample, the 2SLS estimates are negative, relatively large and statistically significant for most groups.

\footnotetext{
32 Note that we follow the same sample requirement, and use the change in employment rate of male workers aged $25-45$ in period t-1 and aged 35-55 in period $t$.

${ }^{33}$ We also estimated a similar model using the initial location of workers -instead of their actual location--to compute the employment rates, and no effect was found.
} 
For blue-collar workers as a whole, a 10 percentage point increase in immigration is associated with wages lower by one log point. In addition, an important result is that the size of the impact is quite heterogeneous across groups, with much larger negative effects on wages for low-skill workers in the non-tradable sector and particularly so in the construction sector. Specifically, for low-skill construction workers, the estimates predict that a 10 p.p. increase in the immigrant share decreases wages by 4.2 log points, an effect four times larger than for blue-collar workers as a whole.

In Panel B, we estimate the model on those workers who remained in the same occupation and location across the two periods. Focusing on stayers generally attenuates the estimated negative effects on wages, and particularly so for low-skill workers in the nontradable and construction sector, for which the coefficient more than halves.

Clearly, the differences between the estimates in panels A and B reflect the inclusion or not of natives who changed occupation and location between two censuses. To disentangle whether the difference between the two estimates is mainly driven by occupation movers or location movers, Panel B in Table 13 presents the results for the balanced sample excluding location movers only and Panel $\mathrm{C}$ considers in turn the balanced sample excluding occupational movers only. The results in Panel B unambiguously indicate that excluding those who change location dramatically reduces the negative impact of immigration on wages. In contrast, when the sample excludes those who changed occupation (Panel C), the negative wage effect is much larger. This suggests that the wages of location movers are much more negatively affected by immigration than the wages of stayers, while occupational movers experience a smaller variation in their wages.

Finally, Panel C in Table 12 provides results based on cross-sectional variations across occupations. The estimated coefficients are often lower than those obtained in Panel A, and 
most of the time statistically insignificant, showing that cross-sectional estimates that do not follow workers over time tend to be much more imprecise than those in the balanced sample.

We draw two main conclusions from these results. First, there is a strong heterogeneity in the estimated effect of immigration across blue-workers depending on their initial skill and industry. The estimates of the wage effects are four times larger for lowskilled workers initially in the construction sector than for blue-collar workers in the tradable sector. Low-educated immigration clearly does not affect the wages of blue-collar workers in a similar way and disproportionately affects low-skill workers in the non-tradable sector, in particular in the construction sector. Studies using larger skill groups are likely to miss the disproportionate effect that immigration has on these workers.

A second lesson is that it is important to take into account composition effects and endogenous reallocation, as we find the estimated impact to be much larger on the balanced sample than in a cross-section. These differences are driven by the larger wage losses of location movers while the effects are strongly attenuated when the sample also includes occupation movers. In contrast, our results suggest that the wage of occupation movers is much less affected than the wage of stayers. Thus, overall, there are significant differences in the wage impact of immigration even across individuals in the same occupation/location.

\section{Robustness}

In Table 14, we use as an alternative dependent variable the change in the median log daily wages in the cell. Using the median has the advantage of providing estimates relatively insensitive to the presence of outliers. The results tend to be consistent, with largest negative effects in the balanced sample including location and occupation, and with less precisely measured coefficients for cross-sectional variations.

Table 15 examines the sensitivity of the results to the specifications of the baseline model. Indeed, one issue with our instruments might be that the lagged distribution of 
immigrants is correlated with persistent trends in economic dynamism across locations. As a result, the exclusion restriction of our instrument might not be perfectly valid. A simple test of this hypothesis is to check whether the estimates change in an important way when we exclude different sets of control variables. ${ }^{34}$ If the estimates significantly changed, this would indicate that the immigrant inflows predicted by our instrument, which should be orthogonal to other local labour market shocks, are strongly correlated with other factors influencing wages across locations. Specifically, Panel A examines the robustness of estimates using the balanced panel while Panel B reports cross-section estimates. This is done in rows 1 and 2 which respectively include no control (except for time dummies), and regional trends and time dummies. As the estimates are very similar to the baseline results (see Table 12), these patterns are not consistent with the hypothesis that our instrument might be correlated with unobserved determinants of wage changes across locations.

Next, we investigate the extent to which the results might be driven by large cities such as Paris, Marseilles or Lyons, which attract a disproportionate share of immigrants. Row 3 presents estimates where the 3 largest commuting zones have been excluded from the sample while row 4 reports unweighted regressions. Results are broadly similar in these two models except for the group of low-skill construction workers for whom estimates tend to become smaller and more imprecise.

Panel B reports the same robustness tests performed using the cross-section sample. We also find the baseline results to be reasonably robust across most specifications but the precision of the estimates dramatically diminishes in some specifications.

\footnotetext{
${ }^{34}$ Another good reason to exclude control variables that are specific to the location is that these controls might be endogenous. This would be the case for example if variables such as the share of workers in the construction sector or in the manufacturing sector were significantly affected by immigrant inflows.
} 


\section{VI) Discussion}

In this paper, we have revisited the impact of immigration on the labour market outcomes of natives. We have used the initial occupations of natives to isolate the groups of workers that were likely to be more in competition with low-educated immigrants. Our rich dataset has provided us with a unique opportunity to investigate heterogeneity in the impact of immigration on various outcomes while assessing the importance of composition effects.

We have outlined the importance and the consequences of endogenous mobility across local labour markets and occupations in response to immigrant inflows. Our findings show that immigrant inflows are correlated with both native outflows, and with a reallocation of natives to occupations with less routine tasks. While location-movers tend to be negatively selected from the sending population, those moving to occupations with less routine tasks tend to be positively selected.

Importantly, our results point to a strong heterogeneity across and within occupation groups in the impact of immigration. The wages of blue-collar workers initially in the tradable sector are much less affected by immigrant inflows and these workers are also more likely to change occupation in response to immigration than their counterparts in the non-tradable sectors. At the other extreme of the spectrum, low-skill construction workers experience a large negative effect on wages and tend not to move to different occupation in response to immigrant inflows. Interestingly, the effects are heterogeneous even within groups, with natives moving occupation (resp. location) experiencing lower (resp. larger) wage decreases.

There are however several limitations to the previous analysis. First, because we wanted to minimise the risks that our results might be biased by non-participation, we have focused on prime aged male workers. According to recent work from Smith (2012), low-skill immigrants might be more in competition with younger workers that were not included in our analysis. Similarly, we did not include women in our analysis as the treatment of labour market 
participation creates an additional complexity for this group. An evaluation of the impact of immigration on young workers and women would be of substantial interest for future work.

\section{Appendix}

\section{Data appendix}

Occupations: The DADS contains information on 27 different categories of occupations before 1983 and 36 categories afterward. The category "Blue-collar workers" aggregates 7 distinct categories of occupations over the period. We merge these occupations with tasks intensity indexes from Goos et al. (2010, Table 4 p.49) based on the Occupational Information Network (ONET) database.

Crosswalk tables for industry classifications: We use the industry classification which remained unchanged for the longest period of time in the data. The NAP (Nomenclatures d'Activités et de Produits 1973) is used in the 1975, 1982 and 1990 censuses and in the DADS until 1993. We have created crosswalk tables with other industry classifications to match them with the NAP at the four digit level. The NAF (Nomenclature d'Activité Française) is used in the 1999 Census and in the DADS from 1993 to 2002. For the match between NAP and NAF, we have used the 1994 LFS (Enquête emploi) in which both codes are given to establish a match at the four digit levels. Similarly, when several possibilities existed, we have kept the most frequent correspondence. In both cases, the match has been completed manually to include exhaustively all codes in the correspondence table at the four digit level.

Education in Census data: The education variable reported in the Census indicates the diploma received by the individual. We use the variable DIP in the 1968, 1975 and 1982 censuses, DIPL1 in the 1990 Census and DIPL in the 1999 Census. We classify individuals in four groups: Primary education, Secondary education, High School and College. Primary education level includes individuals which declare to have no diploma and people having the primary school certificate. Secondary education level includes individuals which report to 
have a diploma of a level equivalent to the Diplôme National du Brevet (BEPC) and includes individuals holding a CAP or a BEP. High school education includes individuals who have a diploma equivalent to the Baccalaureate. This group also includes general, professional or technical Baccalaureate graduates. College level includes all individuals with a diploma of a level superior to the Baccalaureate. 


\section{References}

Abowd, John M., Francis Kramarz and David N. Margolis (1999), 'High wage workers and high wage firms', Econometrica 67(2), 251-334.

Acemoglu, Daron and David. Autor (2011), 'Skills, tasks and technologies: Implications for employment and earnings', Handbook of Labor Economics, Vol. 4, Elsevier.

Aeberhardt, Romain, Pauline Givord and Claire Marbot (2012), 'Minimum wage and wage inequality in france: An unconditional quantile regresion approach'. Working Paper G201207, D3E, INSEE.

Autor, David H., Frank Levy and Richard J. Murnane (2003), 'The skill content of recent technological change: An empirical exploration', The Quarterly Journal of Economics 118(4), 1279-1333.

Aydemir, Abdurrahman and George J. Borjas (2007), 'Cross-country variation in the impact of international migration: Canada, Mexico, and the United States', Journal of the European Economic Association 5(4), 663-708.

Aydemir, Abdurrahman and George J. Borjas (2011), 'Attenuation bias in measuring the wage impact of immigration', Journal of Labor Economics 29(1), 69-112.

Beaudry, Paul, Mark Doms and Ethan Lewis (2010), 'Should the personal computer be considered a technological revolution? evidence from U.S. metropolitan areas', Journal of Political Economy 118(5), 988 - 1036.

Borjas, George J (1999), 'The economic analysis of immigration', Handbook of Labor Economics, 3, 1697-1760. Elsevier.

Borjas, George J. (2003), 'The labor demand curve is downward sloping: reexamining the impact of immigration on the labor market', Quarterly Journal of Economics 118(4), 13351374.

Borjas, George J. (2006), 'Native internal migration and the labor market impact of immigration', Journal of Human Resources 41(2), 221.

Bratsberg, Bernt and Oddbjørn Raaum (2012), 'Immigration and wages: evidence from construction', The Economic Journal, 122(1), 1177-1205

Bratsberg, Bernt, Oddbjørn Raaum, Marianne Røed and Pål Schøne (2014), 'Immigration wage effects by origin', Scandinavian Journal of Economics . 116(2), 356-393.

Card, David (2001), 'Immigrant inflows, native outflows, and the local market impacts of higher immigration', Journal of Labor Economics 19(1), 22-64.

Card, David (2009), 'Immigration and inequality', American Economic Review (Papers and Proceedings) 99(2), 1-21. 
Card, David and John DiNardo (2000), 'Do immigrant inflows lead to native outflows?', The American Economic Review, 90(2), 360-367.

Cattaneo, Cristina, Carlo V. Fiorio, and Giovanni Peri (2015) 'What Happens to the Careers of European Workers When Immigrants “Take Their Jobs"?', Journal of Human Resources, July 1, 2015 50:655-693.

Combes, Pierre-Philippe, Gilles Duranton and Laurent Gobillon (2008), 'Spatial wage disparities: Sorting matters!', Journal of Urban Economics, 63(2), 723-742.

Combes, Pierre-Philippe, Gilles Duranton, Laurent Gobillon and Sébastien Roux (2012), 'Sorting and Local Wage and Skill Distributions in France', Regional Science and Urban Economics, Volume 42, Issue 6, November 2012, Pages 913-930.

Cortes, Patricia (2008), 'The Effect of Low-Skilled Immigration on U.S. Prices: Evidence from CPI Data’, Journal of Political Economy, 116(3), 381-422.

D’Amuri, Francesco and Giovanni Peri (2014), 'Immigration, Jobs, And Employment Protection: Evidence From Europe Before And During The Great Recession', Journal of the European Economic Association, European Economic Association, vol. 12(2), pages 432-464.

De New, John P. and Klaus F. Zimmermann (1994), 'Native Wage Impacts of Foreign Labor: a Random Effects Panel Analysis', Journal of Population Economics 7, 177-192.

Dustmann, Christian and Ian Preston (2012). 'Comment: Estimating the effect of immigration on wages'. Journal of the European Economic Association, 10(1), 216-223.

Dustmann, Christian, Tommaso Frattini and Ian Preston (2013), 'The effect of immigration along the distribution of wages', The Review of Economic Studies 80(1), 145 - 173.

Dustmann, Christian and Albrecht Glitz (2015), 'How do industries and firms respond to changes in local labor supply?', Journal of Labor Economics 33(3).

Foged, Mette and G. Peri (2016) 'The labor market effects of immigrants: new analysis using longitudinal data', American Economic Journal: Applied Economics, vol. 8, No. 2, April 2016, pp. 1-34.

Friedberg, Rachel M. (2000). 'You can't take it with you? Immigrant assimilation and the portability of human capital'. Journal of Labor Economics, 18(2), 221-251.

Gibbons, Robert, Lawrence Katz, Thomas Lemieux and Daniel Parent (2005) 'Comparative advantage, learning, and sectoral wage determination', Journal of Labor Economics 23, (October 2005) 681-724

Goos, Maarten and Alan Manning (2007), 'Lousy and lovely jobs: The rising polarization of work in britain', The Review of Economics and Statistics 89(1), 118-133.

Goos, Maarten, Alan Manning and Anna Salomons, 2010. "Explaining job polarization in Europe: The roles of technology, globalization and institutions," CEP Discussion Papers DP1026, Centre for Economic Performance, LSE. Published as "Explaining job polarization: 
Routine-biased technological change and offshoring." American Economic Review, 104(8): 2509-26, August 2014.

Hanson, Gordon and Matthew J. Slaughter (2002), 'Labor-market adjustment in open economies: Evidence from us states’, Journal of International Economics 57(1), 3-29.

Hatton, Timothy J. and Massimiliano Tani (2005), 'Immigration and inter-regional mobility in the uk, 1982-2000', Economic Journal 115(507), F342-F358.

Hunt, Jennifer (2012), 'The impact of immigration on the educational attainment of natives', Journal of Human Resources, forthcoming.

Hunt, Jennifer and Marjolaine Gauthier-Loiselle (2010), 'How much does immigration boost innovation?’, American Economic Journal: Macroeconomics 2(2), 31-56.

Koubi, Malik and Sébastien Roux (2004), 'Refonte du panel DADS : principes et premières estimations d'emploi et de salaire'. Version provisoire, Note interne 204/F240, INSEE.

Manacorda, Marco, Alan Manning and Jonathan Wadsworth (2012), 'The impact of immigration on the structure of wages: Theory and evidence from Britain', Journal of the European Economic Association 10(1), 120-151.

Llull, Joan (2014), 'Immigration, wages, and education: A labor market equilibrium structural model', Barcelona GSE Working Paper 711.

Mazzolari, Francesca, and David Neumark (2012), 'Immigration and product diversity'. Journal of Population Economics 25(3), 1107-1137.

Mocetti, Sauro and Carmine Porello (2010), 'How does immigration affect native internal mobility? New evidence from Italy', Regional Science and Urban Economics 40(6), 427-439.

Moretti, Enrico (2011), 'Local Labor Markets', in Handbook of Labor Economics, vol. 4, chapter 14, pp. 1237-1313. Elsevier.

Ortega, Javier and Gregory Verdugo (2014), 'The impact of immigration on the French labor market: why so different?', Labour Economics 29, 14-27.

Orrenius, Pia M., and Madeline Zavodny (2007). 'Does immigration affect wages? A look at occupation-level evidence.' Labour Economics, 14(5), 757-773.

Ottaviano, Gianmarco I.P. and Giovanni Peri (2012), 'Rethinking the effect of immigration on wages', Journal of the European Economic Association 10(1), 152-198.

Peri, Giovanni and Chad Sparber (2009), 'Task specialization, comparative advantages, and the effects of immigration on wages', American Economic Journal: Applied Economics 1(3), $135-169$.

Royer, Jean-François (2007), 'Quatre observations sur la mobilité résidentielle en France métropolitaine'. Série des documents de travail du CREST, No. 2007-10, INSEE. 
Smith, Christopher L. (2012), 'The impact of low-skilled immigration on the youth labor market', Journal of Labor Economics 30(1), 55 - 89.

Verdugo, Gregory (2014). The great compression of the French wage structure, 1969-2008. Labour Economics, 28, 131-144.

Wozniak, Abigail and Thomas J. Murray (2012), 'Timing is everything: Short-run population impacts of immigration in U.S. cities', Journal of Urban Economics 72(1), 60 - 78. 


\section{Tables}

Table 1 : Share of Foreign Born Workers among Blue-collar Workers across Selected Industries and Regions in France in 1999

\begin{tabular}{|c|c|c|c|c|c|}
\hline \multirow[t]{2}{*}{ Industry } & \multicolumn{4}{|c|}{ Share of foreign born workers } & $\begin{array}{c}\text { Share total } \\
\text { Emnlovment }\end{array}$ \\
\hline & France & Paris & Lyons & Brittany & \\
\hline Non-Tradable & 14.5 & 32.8 & 16.2 & 3.4 & 62.0 \\
\hline Tradable & 10.6 & 24.2 & 15.7 & 1.9 & 31.1 \\
\hline Construction & 20.2 & 45.7 & 23.9 & 5.0 & 16.4 \\
\hline
\end{tabular}

Source: DADS Panel. All figures refer to blue-collar workers only. Paris and Lyons regions refer respectively to the region "Ile de France" and "Rhône-Alpes".

Table 2: Share of Foreign Born among Construction Workers in the Paris and Brittany regions, 1976-2007

\begin{tabular}{|l|r|r|r|r|r|}
\hline & \multicolumn{1}{|c|}{$\mathbf{1 9 7 6}$} & \multicolumn{1}{|c|}{$\mathbf{1 9 8 2}$} & \multicolumn{1}{|c|}{1990} & \multicolumn{1}{|c|}{1999} & \multicolumn{1}{c|}{$\mathbf{2 0 0 7}$} \\
\hline Paris & 37.2 & 37.1 & 35.6 & 45.7 & 41.7 \\
\hline Brittany & 3.8 & 4.2 & 4 & 5.0 & 6.9 \\
\hline
\end{tabular}

Source: DADS Panel. All figures refer to blue-collar workers.

Table 3: First Stage Results

\begin{tabular}{|l|l|l|l|}
\hline \multicolumn{5}{|c|}{$\begin{array}{c}\text { Dependent variable : Change in Low-Educated } \\
\text { Immigrant Ratio } \Delta p_{l t}\end{array}$} \\
\hline & \multicolumn{1}{|c|}{$(1)$} & \multicolumn{1}{c|}{$(2)$} & \multicolumn{1}{c|}{$(3)$} \\
\hline Predicted change & $0.207^{* * *}$ & $0.162^{* * *}$ & $0.145^{* * *}$ \\
\hline & $(0.039)$ & $(0.022)$ & $(0.023)$ \\
\hline First Stage F-stat & 28.5 & 54.7 & 37.9 \\
\hline R-squared & 0.12 & 0.29 & 0.27 \\
\hline Additional Controls & No & Yes & Yes \\
\hline Weight & Yes & Yes & No \\
\hline
\end{tabular}

Note: All regressions use 1188 observations and include a full set of regions and time fixed effects. Additional controls included in the regressions when indicated. Standard errors are clustered at the commuting zone level. Regressions are weighted by $\left(1 / N_{k l t}+1 / N_{k l t-1}\right)^{-1 / 2}$ except when indicated otherwise. A $(*)$ denotes statistical significance at the $10 \%$ level, a $(* *)$ denotes at the $5 \%$ level, a $(* * *)$ at the $1 \%$ level. 
Table 4: Impact of Low-Educated Immigration on

Native Outflows at the Commuting Zone Level

\section{DADS Data}

Dependent variable: Outflow rate between $t / t-1$

Sample: Male workers 25-45 in $t-1,35-55$ in $t$.

\begin{tabular}{|l|l|l|l|l|l|l|}
\hline $\begin{array}{l}\text { Initial } \\
\text { occupation }\end{array}$ & \multicolumn{1}{|c|}{$\begin{array}{c}\text { All } \\
\text { Blue-Collar }\end{array}$} & Tradable & $\begin{array}{c}\text { Non- } \\
\text { tradable }\end{array}$ & Construction & $\begin{array}{c}\text { Non-tradable } \\
\text { Low-Skill }\end{array}$ & $\begin{array}{c}\text { Construction } \\
\text { Low-Skill }\end{array}$ \\
\hline \multicolumn{7}{|c|}{ OLS } \\
\hline$\Delta p_{l t}$ & $0.132^{* * *}$ & $0.104 * * *$ & $0.154^{* * *}$ & $0.143^{* * *}$ & $0.156^{* * *}$ & $0.104 * * *$ \\
\hline & $(0.025)$ & $(0.092)$ & $(0.031)$ & $(0.026)$ & $(0.047)$ & $(0.040)$ \\
\hline & \multicolumn{7}{|c|}{ 2SLS } \\
\hline$\Delta p_{l t}$ & $0.183^{*}$ & 0.106 & $0.218^{*}$ & $0.389^{* * *}$ & 0.173 & $0.188^{*}$ \\
\hline & $(0.095)$ & $(0.097)$ & $(0.114)$ & $(0.108)$ & $(0.128)$ & $(0.111)$ \\
\hline $\begin{array}{l}\text { Baseline } \\
\text { rate }\end{array}$ & 0.20 & 0.14 & 0.25 & 0.22 & 0.25 & 0.31 \\
\hline
\end{tabular}

Note: All regressions use 1188 observations and include a full set of regions and time fixed effects. Additional controls included in the regressions. Standard errors are clustered at the commuting zone level. Regressions are weighted by $\left(1 / N_{k l t}+1 / N_{k l t-1}\right)^{-1 / 2}$. A $\left(^{*}\right)$ denotes statistical significance at the $10 \%$ level, a $(* *)$ denotes at the $5 \%$ level, a $(* * *)$ at the $1 \%$ level. 
Table 5: Selection and Native Outflows

\begin{tabular}{|c|c|c|c|c|c|c|c|c|}
\hline \multicolumn{9}{|c|}{ Dependent variable : Outflow probability between $t / t-1$} \\
\hline & \multicolumn{4}{|c|}{ A. All Blue-Collar } & \multicolumn{4}{|c|}{ B. Tradable } \\
\hline & (1) & (2) & (3) & (4) & (1) & (2) & (3) & (4) \\
\hline \multirow[t]{2}{*}{$\Delta p_{l t}$} & $0.183^{*}$ & $0.147 *$ & $0.163 * *$ & $0.168 *$ & 0.106 & 0.115 & 0.124 & 0.099 \\
\hline & $(0.095)$ & $(0.079)$ & $(0.079)$ & $(0.098)$ & $(0.097)$ & $(0.094)$ & $(0.93)$ & $(0.119)$ \\
\hline \multirow[t]{2}{*}{ Wage (t-1) } & & & $-0.122 * * *$ & $-0.119 * * *$ & & & $-0.094 * * *$ & $-0.110 * * *$ \\
\hline & & & $(0.005)$ & $(0.018)$ & & & $(0.008)$ & $(0.025)$ \\
\hline \multirow[t]{2}{*}{ Wage(t-1) x $\Delta p_{l t}$} & & & & -0.065 & & & & 0.363 \\
\hline & & & & $(0.400)$ & & & & $(0.557)$ \\
\hline \multirow[t]{2}{*}{$\mathrm{N}$} & 1188 & 313381 & 313381 & 313381 & 1188 & 141891 & 141891 & 141891 \\
\hline & \multicolumn{4}{|c|}{ C. Non-Tradable } & \multicolumn{4}{|c|}{ D. Construction } \\
\hline \multirow[t]{2}{*}{$\Delta p_{l t}$} & $0.218 *$ & 0.140 & 0.153 & 0.177 & $0.389 * * *$ & $0.351 *$ & $0.367 *$ & 0.621 \\
\hline & $(0.114)$ & $(0.093)$ & $(0.094)$ & $(0.110)$ & $(0.108)$ & $(0.188)$ & $(0.194)$ & $(0.528)$ \\
\hline \multirow[t]{2}{*}{ Wage (t-1) } & & & $-0.096^{* * *}$ & $-0.083^{*} * *$ & & & $-0.062 * * *$ & 0.059 \\
\hline & & & $(0.006)$ & $(0.017)$ & & & $(0.011)$ & $(0.130)$ \\
\hline \multirow{2}{*}{ Wage(t-1) × $\Delta p_{l t}$} & & & & -0.270 & & & & -2.319 \\
\hline & & & & $(0.350)$ & & & & $(2.563)$ \\
\hline \multirow[t]{2}{*}{$\mathrm{N}$} & 1188 & 171484 & 171484 & 171484 & 1188 & 54586 & 54586 & 54586 \\
\hline & \multicolumn{4}{|c|}{ E. Non-Tradable Low-Skill } & \multicolumn{4}{|c|}{ F. $\quad$ Construction Low-Skill } \\
\hline \multirow[t]{2}{*}{$\Delta p_{l t}$} & 0.173 & $0.135^{*}$ & $0.139 *$ & $0.146^{*}$ & $0.188^{*}$ & 0.163 & 0.170 & 0.190 \\
\hline & $(0.128)$ & $(0.079)$ & $(0.079)$ & $(0.086)$ & $(0.111)$ & $(0.125)$ & $(0.126)$ & $(0.156)$ \\
\hline \multirow[t]{2}{*}{ Wage (t-1) } & & & $-0.111 * * *$ & $-0.106 * * *$ & & & $-0.063 * * *$ & $-0.054 *$ \\
\hline & & & $(0.008)$ & $(0.016)$ & & & $(0.018)$ & $(0.028)$ \\
\hline Wage $(\mathrm{t}-1) \mathrm{x}$ & & & & -0.120 & & & & -0.215 \\
\hline$\Delta p_{l t}$ & & & & $(0.278)$ & & & & $(0.463)$ \\
\hline $\mathrm{N}$ & 1188 & 81223 & 81223 & 81223 & 25439 & 25439 & 25439 & 25439 \\
\hline
\end{tabular}

Note: All regressions include a full set of regions and time fixed effects and are estimated with 2SLS. Additional controls included in the regressions. Standard errors are clustered at the commuting zone level in column 1 and at the commuting zone by year level in other columns. A (*) denotes statistical significance at the $10 \%$ level, a $(* *)$ denotes at the $5 \%$ level, a $(* * *)$ at the $1 \%$ level. 
Table 6: Census data Evidence on the Impact of Low-Educated Immigration on Native Outflows

Census Data

\begin{tabular}{|l|l|l|l|c|}
\hline & \multicolumn{1}{|c|}{$\begin{array}{c}\text { Primary } \\
\text { Education }\end{array}$} & $\begin{array}{c}\text { Secondary } \\
\text { Education }\end{array}$ & $\begin{array}{c}\text { High- } \\
\text { School }\end{array}$ & University \\
\hline & \multicolumn{4}{|c|}{ Dependent variable: Outflows between $t / t-1$} \\
\hline & \multicolumn{5}{|c|}{ OLS } \\
\hline$\Delta p_{l t}$ & $0.026^{* *}$ & 0.022 & $-0.037^{* *}$ & $-0.040^{*}$ \\
\hline & $(0.012)$ & $(0.016)$ & $(0.019)$ & $(0.024)$ \\
\hline & \multicolumn{5}{|c|}{ 2SLS } \\
\hline$\Delta p_{l t}$ & $0.242^{* *}$ & $0.278^{* *}$ & 0.242 & 0.127 \\
\hline & $(0.109)$ & $(0.144)$ & $(0.190)$ & $(0.208)$ \\
\hline
\end{tabular}

Note: All regressions use 1188 observations and include a full set of regions and time fixed effects. Additional controls included in the regressions. Standard errors are clustered at the commuting zone level. Regressions are weighted by $\left(1 / N_{k l t}+1 / N_{k l t-1}\right)^{-1 / 2}$. A (*) denotes statistical significance at the $10 \%$ level, a (**) denotes at the $5 \%$ level, a $(* * *)$ at the $1 \%$ level. 
Table 7: Impact of Low-Educated Immigration on Occupational Change

\begin{tabular}{|c|c|c|c|c|c|c|}
\hline \multicolumn{7}{|c|}{ Sample: Male $25-45$ in $\mathrm{t}-1,35-55$ in $\mathrm{t}$} \\
\hline $\begin{array}{l}\text { Initial } \\
\text { occupation }\end{array}$ & Blue-Collar & Tradable & Non-tradable & Construction & $\begin{array}{l}\text { Low Skill } \\
\text { Non- } \\
\text { tradable } \\
\end{array}$ & $\begin{array}{l}\text { Low Skill } \\
\text { Construction }\end{array}$ \\
\hline \multicolumn{7}{|c|}{ A. Dependent variable : Share of workers in a different occupation groups in $t+1$} \\
\hline & \multicolumn{6}{|c|}{ OLS } \\
\hline \multirow{3}{*}{$\Delta p_{l t}$} & 0.007 & 0.006 & 0.026 & -0.004 & -0.003 & -0.015 \\
\hline & $(0.021)$ & $(0.035)$ & $(0.022)$ & $(0.023)$ & $(0.030)$ & $(0.043)$ \\
\hline & \multicolumn{6}{|c|}{ 2SLS } \\
\hline \multirow[t]{2}{*}{$\Delta p_{l t}$} & $0.200 * * *$ & 0.127 & $0.103 *$ & $0.152 *$ & 0.108 & 0.016 \\
\hline & $(0.045)$ & $(0.087)$ & $(0.055)$ & $(0.088)$ & $(0.084)$ & $(0.098)$ \\
\hline $\begin{array}{l}\text { Baseline } \\
\text { Rate }\end{array}$ & 0.21 & 0.30 & 0.30 & 0.32 & 0.38 & 0.36 \\
\hline \multicolumn{7}{|c|}{ B. Dependent variable : Share of workers employees in $t+1$} \\
\hline & \multicolumn{6}{|c|}{ OLS } \\
\hline \multirow[t]{3}{*}{$\Delta p_{l t}$} & 0.002 & 0.009 & 0.000 & 0.012 & -0.000 & 0.024 \\
\hline & $(0.010)$ & $(0.012)$ & $(0.011)$ & $(0.015)$ & $(0.019)$ & $(0.036)$ \\
\hline & \multicolumn{6}{|c|}{ 2SLS } \\
\hline \multirow[t]{2}{*}{$\Delta p_{l t}$} & $0.053^{* *}$ & 0.026 & $0.070 * * *$ & 0.078 & 0.031 & 0.078 \\
\hline & $(0.022)$ & $(0.046)$ & $(0.024)$ & $(0.053)$ & $(0.038)$ & $(0.095)$ \\
\hline $\begin{array}{l}\text { Baseline } \\
\text { Rate }\end{array}$ & 0.06 & 0.04 & 0.07 & 0.03 & 0.07 & 0.04 \\
\hline \multicolumn{7}{|c|}{ C. Dependent variable : Share of workers technicians in $t+1$} \\
\hline & \multicolumn{6}{|c|}{ OLS } \\
\hline \multirow[t]{3}{*}{$\Delta p_{l t}$} & -0.009 & -0.023 & 0.001 & 0.000 & -0.007 & 0.008 \\
\hline & $(0.012)$ & $(0.015)$ & $(0.013)$ & $(0.014)$ & $(0.016)$ & $(0.023)$ \\
\hline & \multicolumn{6}{|c|}{ 2SLS } \\
\hline \multirow[t]{2}{*}{$\Delta p_{l t}$} & $0.083 * *$ & $0.095^{* *}$ & $0.079 *$ & 0.016 & $0.077^{*}$ & 0.035 \\
\hline & $(0.038)$ & $(0.044)$ & $(0.044)$ & $(0.054)$ & $(0.043)$ & $(0.064)$ \\
\hline \multirow[t]{3}{*}{$\begin{array}{l}\text { Baseline } \\
\text { Rate }\end{array}$} & 0.10 & 0.10 & 0.09 & 0.07 & 0.10 & 0.08 \\
\hline & \multicolumn{6}{|c|}{ D. Dependent variable : Share of workers managers in $t+1$} \\
\hline & \multicolumn{6}{|c|}{ OLS } \\
\hline \multirow[t]{3}{*}{$\Delta p_{l t}$} & $0.012 *$ & 0.010 & $0.014 * *$ & 0.010 & $0.014 *$ & 0.007 \\
\hline & $(0.006)$ & $(0.012)$ & $(0.006)$ & $(0.007)$ & $(0.007)$ & $(0.009)$ \\
\hline & \multicolumn{6}{|c|}{ 2SLS } \\
\hline \multirow[t]{2}{*}{$\Delta p_{l t}$} & $0.040 * *$ & 0.058 & 0.019 & -0.005 & 0.045 & -0.019 \\
\hline & $(0.006)$ & $(0.012)$ & $(0.019)$ & $(0.027)$ & $(0.030)$ & $(0.019)$ \\
\hline $\begin{array}{l}\text { Baseline } \\
\text { Rate }\end{array}$ & 0.04 & 0.04 & 0.04 & 0.03 & 0.03 & 0.02 \\
\hline
\end{tabular}

Note: All regressions use 1188 observations and include a full set of regions and time fixed effects. Additional controls included in the regressions. Standard errors are clustered at the commuting zone level. Regressions are weighted by $\left(1 / N_{k l t}+1 / N_{k l t-1}\right)^{-1 / 2}$. A (*) denotes statistical significance at the $10 \%$ level, a $(* *)$ denotes at the $5 \%$ level, a $(* * *)$ at the $1 \%$ level. 
Table 8: Impact of Immigration on Average Task Contents

\begin{tabular}{|c|c|c|c|c|c|c|}
\hline \multicolumn{7}{|c|}{ Sample: Male $25-45$ in $\mathrm{t}-1,35-55$ in $\mathrm{t}$} \\
\hline $\begin{array}{l}\text { Initial } \\
\text { occupation }\end{array}$ & $\begin{array}{l}\text { Blue- } \\
\text { Collar }\end{array}$ & Tradable & Non-tradable & Construction & $\begin{array}{l}\text { Low Skill } \\
\text { Non- } \\
\text { tradable }\end{array}$ & $\begin{array}{c}\text { Low Skill } \\
\text { Construction }\end{array}$ \\
\hline \multicolumn{7}{|c|}{ Dependent variable : Change in average routine task $t / t-1$} \\
\hline & \multicolumn{6}{|c|}{ A. Balanced sample } \\
\hline & \multicolumn{6}{|c|}{ OLS } \\
\hline \multirow[t]{3}{*}{$\Delta p_{l t}$} & 0.006 & 0.019 & -0.017 & -0.044 & -0.002 & -0.023 \\
\hline & $(0.037)$ & $(0.051)$ & $(0.039)$ & $(0.039)$ & $(0.053)$ & $(0.071)$ \\
\hline & \multicolumn{6}{|c|}{2 SLS } \\
\hline \multirow[t]{2}{*}{$\Delta p_{l t}$} & $-0.385 * * *$ & $-0.341 * * *$ & $-0.367 * * *$ & -0.182 & $-0.216^{* *}$ & -0.109 \\
\hline & $(0.082)$ & $(0.127)$ & $(0.099)$ & $(0.121)$ & $(0.100)$ & $(0.164)$ \\
\hline \multirow[t]{3}{*}{$\begin{array}{l}\text { Baseline } \\
\text { Rate }\end{array}$} & -0.31 & -0.31 & -0.32 & -0.23 & -0.32 & -0.25 \\
\hline & \multicolumn{6}{|c|}{ B. Cross-section sample } \\
\hline & \multicolumn{6}{|c|}{ OLS } \\
\hline \multirow[t]{3}{*}{$\Delta p_{l t}$} & 0.012 & $0.027 * * *$ & 0.006 & -0.003 & $0.019 *$ & -0.021 \\
\hline & $(0.008)$ & $(0.009)$ & $(0.010)$ & $(0.008)$ & $(0.011)$ & $(0.011)$ \\
\hline & \multicolumn{6}{|c|}{ 2SLS } \\
\hline \multirow[t]{2}{*}{$\Delta p_{l t}$} & -0.043 & $-0.146 * * *$ & 0.028 & 0.005 & 0.017 & -0.007 \\
\hline & $(0.037)$ & $(0.053)$ & $(0.043)$ & $(0.046)$ & $(0.035)$ & $(0.049)$ \\
\hline
\end{tabular}

Note: All regressions use 1188 observations and include a full set of regions and time fixed effects. Additional controls are included in the regressions. Standard errors are clustered at the commuting zone level. Regressions are weighted by $\left(1 / N_{k l t}+1 / N_{k l t-1}\right)^{-1 / 2}$. A (*) denotes statistical significance at the $10 \%$ level, a (**) denotes at the $5 \%$ level, a $(* * *)$ at the $1 \%$ level. 
Table 9: Selection and Change in Routine Intensity

\begin{tabular}{|c|c|c|c|c|c|c|c|c|}
\hline \multicolumn{9}{|c|}{ Dependent variable : Change in routine intensity of the occupation } \\
\hline & \multicolumn{4}{|c|}{ A. All Blue-Collar } & \multicolumn{4}{|c|}{ B. Tradable } \\
\hline & (1) & (2) & (3) & (4) & (1) & (2) & (3) & (4) \\
\hline \multirow[t]{2}{*}{$\Delta p_{l t}$} & $-0.385 * * *$ & $-0.433 * * *$ & $-0.394 * * *$ & $-0.425 * *$ & $-0.341 * * *$ & $-0.405 * *$ & $-0.357 * *$ & $-0.314 * *$ \\
\hline & $(0.082)$ & $(0.148)$ & $(0.137)$ & $(0.171)$ & $(0.127)$ & $(0.179)$ & $(0.170)$ & $(0.165)$ \\
\hline \multirow[t]{2}{*}{ Wage (t-1) } & & & $-0.299 * * *$ & $-0.316 * * *$ & & & $-0.491 * * *$ & $-0.465 * * *$ \\
\hline & & & $(0.010)$ & $(0.029)$ & & & $(0.016)$ & $(0.031)$ \\
\hline \multirow[t]{2}{*}{ Wage(t-1) x $\Delta p_{l t}$} & & & & 0.379 & & & & -0.626 \\
\hline & & & & $(0.624)$ & & & & $(0.650)$ \\
\hline \multirow[t]{2}{*}{$\mathrm{N}$} & 1188 & 313381 & 313381 & 313381 & 1188 & 141891 & 141891 & 141891 \\
\hline & \multicolumn{4}{|c|}{ C. Non-Tradable } & \multicolumn{4}{|c|}{ D. Construction } \\
\hline \multirow[t]{2}{*}{$\Delta p_{l t}$} & $-0.367 * * *$ & $-0.376 * *$ & $-0.349 * *$ & $-0.416^{*}$ & -0.182 & -0.362 & -0.289 & -0.446 \\
\hline & $(0.099)$ & $(0.179)$ & $(0.173)$ & $(0.214)$ & 0.121 & $(0.218)$ & $(0.225)$ & $(0.335)$ \\
\hline \multirow[t]{2}{*}{ Wage (t-1) } & & & $-0.193 * * *$ & -0.228 & & & $-0.279 * * *$ & $-0.355 * * *$ \\
\hline & & & $(0.010)$ & $(0.037)$ & & & $(0.019)$ & $(0.089)$ \\
\hline \multirow[t]{2}{*}{ Wage(t-1) x $\Delta p_{l t}$} & & & & 0.735 & & & & 1.434 \\
\hline & & & & $(0.755)$ & & & & $(1.652)$ \\
\hline \multirow[t]{2}{*}{$\mathrm{N}$} & 1188 & 171484 & 171484 & 171484 & 1188 & 54586 & 54586 & 54586 \\
\hline & \multicolumn{4}{|c|}{ E. Non-Tradable Low-Skill } & \multicolumn{4}{|c|}{ F. Construction Low-Skill } \\
\hline \multirow[t]{2}{*}{$\Delta p_{l t}$} & $-0.216^{* *}$ & $-0.214 * *$ & $-0.210^{*}$ & $-0.223 *$ & -0.109 & -0.284 & -0.266 & -0.344 \\
\hline & $(0.100)$ & $(0.119)$ & $(0.121)$ & $(0.126)$ & (0.164) & $(0.249)$ & $(0.251)$ & $(0.262)$ \\
\hline \multirow[t]{2}{*}{ Wage (t-1) } & & & $-0.108 * * *$ & $-0.118 * * *$ & & & $-0.159 * * *$ & $-0.194 * * *$ \\
\hline & & & $(0.014)$ & $(0.022)$ & & & $(0.029)$ & $(0.038)$ \\
\hline \multirow[t]{2}{*}{ Wage(t-1) х $\Delta p_{l t}$} & & & & 0.215 & & & & 0.834 \\
\hline & & & & $(0.356)$ & & & & $(0.535)$ \\
\hline $\mathrm{N}$ & 1188 & 81223 & 81223 & 81223 & 25439 & 25439 & 25439 & 25439 \\
\hline
\end{tabular}

Note: All regressions include a full set of regions and time fixed effects and are estimated with 2SLS. Additional controls included in the regressions. Standard errors are clustered at the commuting zone level in column 1 and at the commuting zone by year level in other columns. A (*) denotes statistical significance at the $10 \%$ level, a $(* *)$ denotes at the $5 \%$ level, a $(* * *)$ at the $1 \%$ level. 
Table 10: Impact of immigration on Number of Days Worked

\section{DADS Data}

Dependent variable : change in log average days of work $\mathrm{t} / \mathrm{t}-1$

Sample: Male 25-45 in t-1, 35-55 in t

\begin{tabular}{|l|c|c|c|c|c|c|}
\hline $\begin{array}{l}\text { Initial } \\
\text { occupation }\end{array}$ & $\begin{array}{c}\text { All } \\
\text { Blue-Collar }\end{array}$ & Tradable & $\begin{array}{c}\text { Non- } \\
\text { tradable }\end{array}$ & Construction & $\begin{array}{c}\text { Non-tradable } \\
\text { Low-Skill }\end{array}$ & $\begin{array}{c}\text { Construction } \\
\text { Low-Skill }\end{array}$ \\
\hline
\end{tabular}

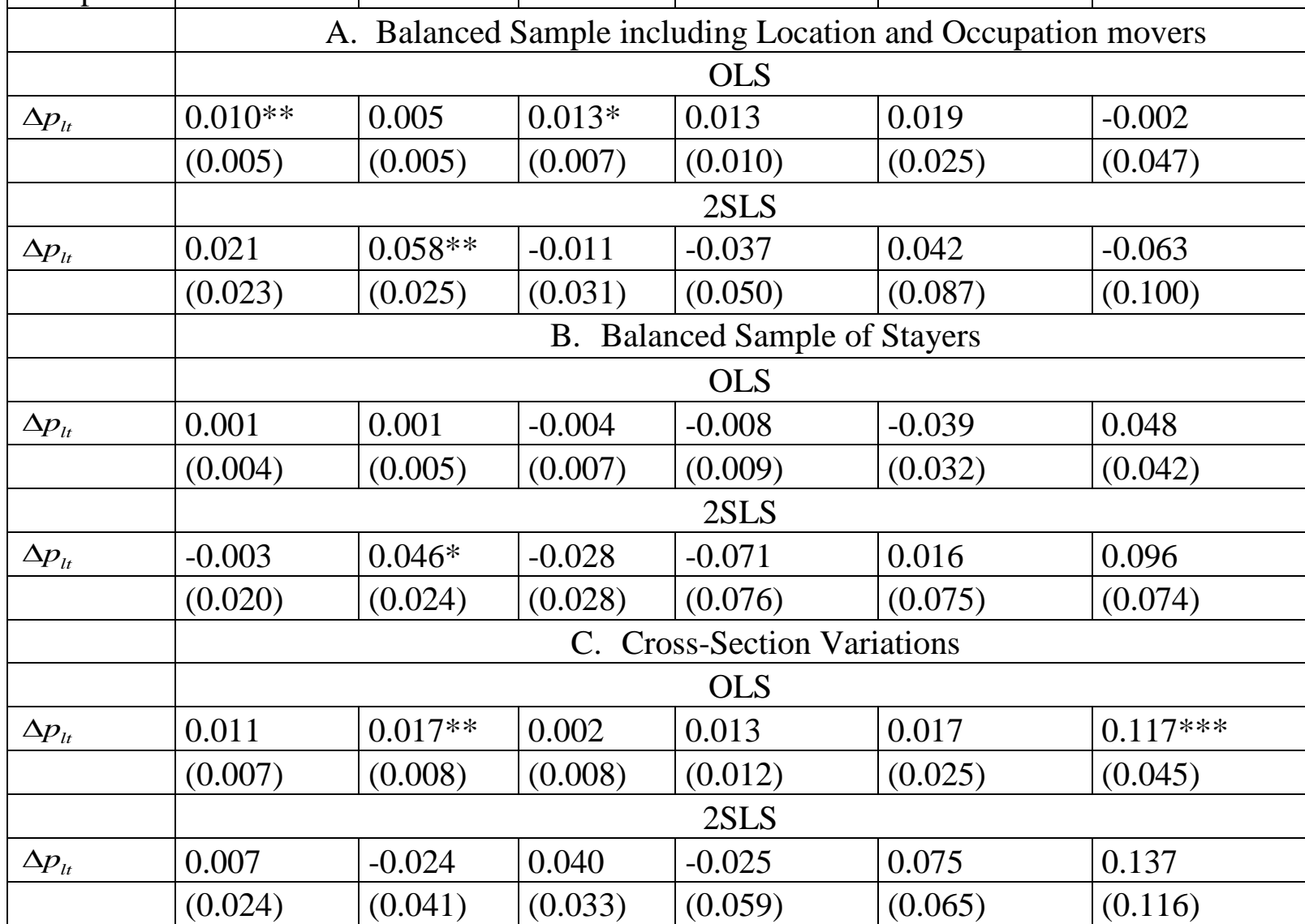

Note: All regressions use 1188 observations and include a full set of regions and time fixed effects. Additional controls are also included in the regressions. Standard errors are clustered at the commuting zone level. Regressions are weighted by $\left(1 / N_{k l t}+1 / N_{k l t-1}\right)^{-1 / 2}$. A (*) denotes statistical significance at the $10 \%$ level, a (**) denotes at the $5 \%$ level, a (***) at the $1 \%$ level. 
Table 11: Additional Evidence on the Impact of Immigration on Employment

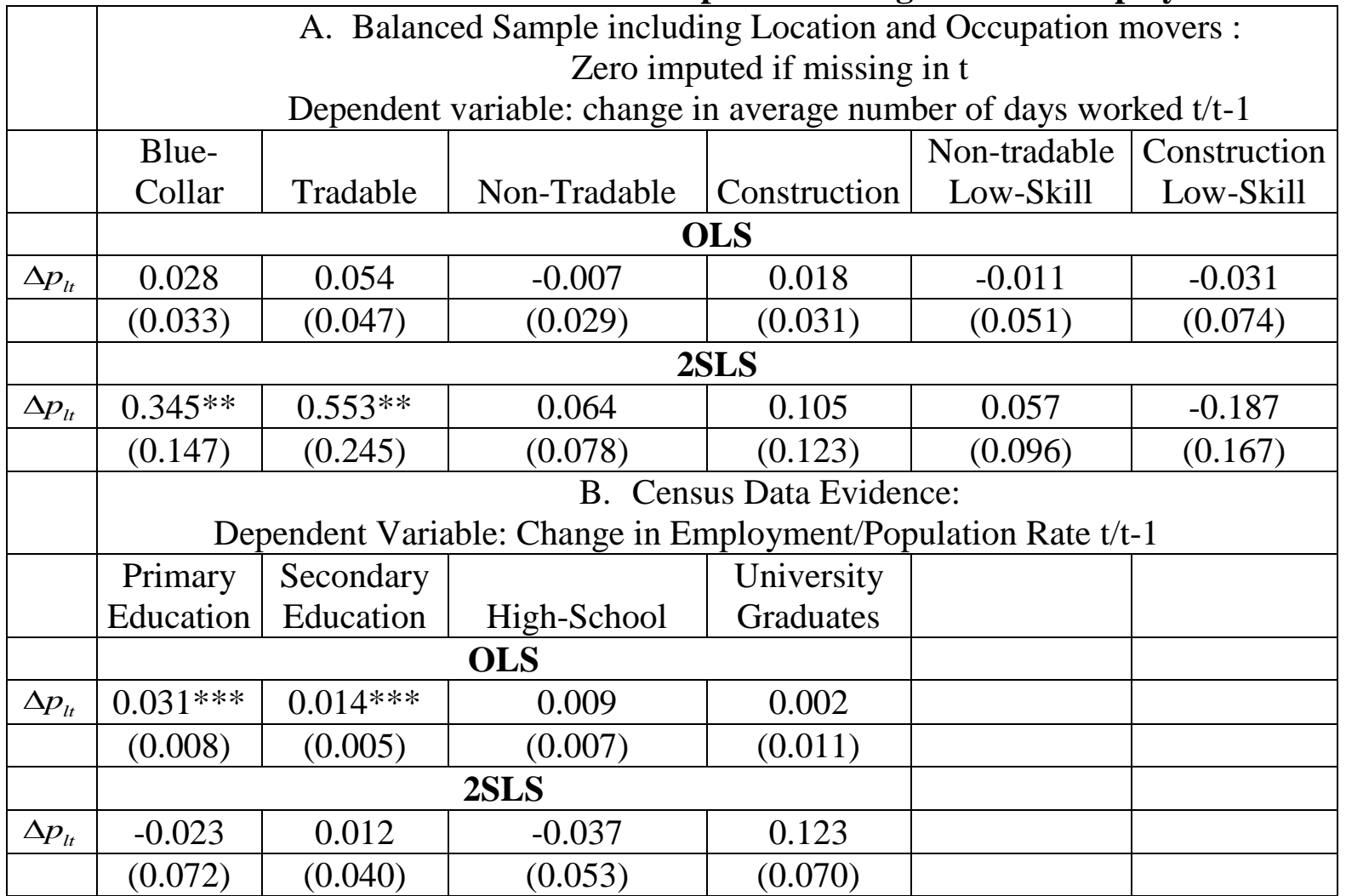

Note: All regressions use 1188 observations and include a full set of regions and time fixed effects. Additional controls are also included in the regressions. Standard errors are clustered at the commuting zone level. Regressions are weighted by $\left(1 / N_{k l t}+1 / N_{k l t-1}\right)^{-1 / 2}$. A (*) denotes statistical significance at the $10 \%$ level, a (**) denotes at the $5 \%$ level, a $(* * *)$ at the $1 \%$ level. 
Table 12: Impact of Immigration on Wages

\section{DADS Data}

Dependent variable : change in average log daily wages $t / t-1$

Sample: Male 25-45 in t-1, 35-55 in t

\begin{tabular}{|l|c|c|c|c|c|c|}
\hline $\begin{array}{l}\text { Initial } \\
\text { occupation }\end{array}$ & $\begin{array}{c}\text { All } \\
\text { Blue-Collar }\end{array}$ & Tradable & $\begin{array}{c}\text { Non- } \\
\text { tradable }\end{array}$ & Construction & $\begin{array}{c}\text { Non-tradable } \\
\text { Low-Skill }\end{array}$ & $\begin{array}{c}\text { Construction } \\
\text { Low-Skill }\end{array}$ \\
\hline
\end{tabular}

\begin{tabular}{|l|l|l|l|l|l|l|}
\hline & \multicolumn{6}{c|}{ A. Balanced Sample including Location and Occupation movers } \\
\hline & \multicolumn{7}{|c|}{ OLS } \\
\hline$\Delta p_{l t}$ & -0.006 & $0.042^{* * *}$ & -0.033 & -0.035 & -0.045 & $-0.158^{*}$ \\
\hline & $(0.017)$ & $(0.014)$ & $(0.027)$ & $(0.048)$ & $(0.036)$ & $(0.082)$ \\
\hline & \multicolumn{7}{|c|}{2 SLS } \\
\hline$\Delta p_{l t}$ & $-0.101^{* *}$ & $-0.098^{*}$ & $-0.135^{* *}$ & -0.053 & $-0.313^{* * *}$ & $-0.417^{* *}$ \\
\hline & $(0.045)$ & $(0.054)$ & $(0.063)$ & $(0.105)$ & $(0.110)$ & $(0.181)$ \\
\hline & \multicolumn{7}{c}{ B. Balanced Sample of Stayers }
\end{tabular}

B. Balanced Sample of Stayers

\begin{tabular}{|l|l|l|l|l|l|l|}
\hline & \multicolumn{7}{|c|}{ OLS } \\
\hline$\Delta p_{l t}$ & 0.016 & $0.022^{*}$ & 0.015 & $0.040^{*}$ & 0.007 & -0.034 \\
\hline & $(0.012)$ & $(0.013)$ & $(0.020)$ & $(0.022)$ & $(0.046)$ & $(0.048)$ \\
\hline & \multicolumn{7}{|c|}{2 SLS } \\
\hline$\Delta p_{l t}$ & $-0.073^{*}$ & $-0.115^{* *}$ & -0.092 & -0.126 & $-0.157^{*}$ & $-0.182^{*}$ \\
\hline & $(0.040)$ & $(0.054)$ & $(0.057)$ & $(0.081)$ & $(0.095)$ & $(0.093)$ \\
\hline & \multicolumn{7}{|c|}{ C. Cross-Sectional Variations } \\
\hline & \multicolumn{7}{|c|}{ OLS } \\
\hline$\Delta p_{l t}$ & 0.015 & $0.050^{* * *}$ & -0.010 & 0.038 & -0.000 & -0.097 \\
\hline & $0.017)$ & $(0.015)$ & $(0.021)$ & $(0.032)$ & $(0.031)$ & $(0.099)$ \\
\hline & \multicolumn{7}{|c|}{2 SLS } \\
\hline$\Delta p_{l t}$ & -0.094 & $-0.142^{*}$ & -0.122 & -0.157 & $-0.216^{*}$ & -0.246 \\
\hline & $(0.063)$ & $(0.084)$ & $(0.077)$ & $(0.126)$ & $(0.125)$ & $(0.163)$ \\
\hline
\end{tabular}

Note: All regressions use 1188 observations and include a full set of regions and time fixed effects. Additional controls are included in the regressions. Standard errors are clustered at the commuting zone level. Regressions are weighted by $\left(1 / N_{k l t}+1 / N_{k l t-1}\right)^{-1 / 2}$ where $N_{k l t}$ represents the size of the occupation group $k$ in location $l$ and year $t$. A (*) denotes statistical significance at the $10 \%$ level, a $\left({ }^{*}\right)$ denotes at the $5 \%$ level, a $(* * *)$ at the $1 \%$ level. 
Table 13: Effect of Including Movers in the Sample

\begin{tabular}{|c|c|c|c|c|c|c|}
\hline \multicolumn{7}{|c|}{ DADS Data } \\
\hline \multicolumn{7}{|c|}{ Dependent variable : change in average daily wages $t / t-1$} \\
\hline \multicolumn{7}{|c|}{ Sample: Male $25-45$ in $\mathrm{t}-1,35-55$ in $\mathrm{t}$} \\
\hline \multirow[t]{2}{*}{$\begin{array}{l}\text { Initial } \\
\text { occupation }\end{array}$} & $\begin{array}{c}\text { All } \\
\text { Blue-Collar }\end{array}$ & Tradable & $\begin{array}{c}\text { Non- } \\
\text { tradable }\end{array}$ & Construction & $\begin{array}{c}\text { Non-tradable } \\
\text { Low-Skill }\end{array}$ & $\begin{array}{c}\text { Construction } \\
\text { Low-Skill }\end{array}$ \\
\hline & \multicolumn{6}{|c|}{ A. Balanced Sample including Location and Occupation movers } \\
\hline \multirow[t]{3}{*}{$\Delta p_{l t}$} & $-0.101 * *$ & $-0.098 *$ & $-0.135 * *$ & -0.053 & $-0.313 * * *$ & $-0.417 * *$ \\
\hline & $(0.045)$ & $(0.054)$ & $(0.063)$ & $(0.105)$ & $(0.110)$ & $(0.181)$ \\
\hline & \multicolumn{6}{|c|}{ B. Balanced Sample without Location Movers } \\
\hline \multirow[t]{3}{*}{$\Delta p_{l t}$} & -0.037 & -0.038 & -0.067 & -0.025 & $-0.249 * *$ & $-0.329 * *$ \\
\hline & $(0.039)$ & $(0.050)$ & $(0.052)$ & $(0.095)$ & $(0.113)$ & $(0.154)$ \\
\hline & \multicolumn{6}{|c|}{ C. Balanced Sample without Occupation Movers } \\
\hline \multirow[t]{3}{*}{$\Delta p_{l t}$} & $-0.172 * * *$ & $-0.129 * *$ & $-0.209 * * *$ & -0.124 & $-0.217 * *$ & -0.173 \\
\hline & $(0.052)$ & $(0.057)$ & $(0.065)$ & $(0.091)$ & $(0.108)$ & $(0.130)$ \\
\hline & \multicolumn{6}{|c|}{ D. Balanced Sample of Stayers } \\
\hline$\Delta p_{l t}$ & $-0.073 *$ & $-0.115 * *$ & -0.092 & -0.126 & $-0.157 *$ & $-0.182 *$ \\
\hline & $(0.040)$ & $(0.054)$ & $(0.057)$ & $(0.081)$ & $(0.095)$ & $(0.093)$ \\
\hline
\end{tabular}

Note: All regressions use 1188 observations and include a full set of regions and time fixed effects and are estimated with 2SLS. Additional controls are included in the regressions. Standard errors are clustered at the commuting zone level. Regressions are weighted by $\left(1 / N_{k l t}+1 / N_{k l t-1}\right)^{-1 / 2}$ where $N_{k l t}$ represents the size of the occupation group $k$ in location $l$ and year $t$. A $(*)$ denotes statistical significance at the $10 \%$ level, a $(* *)$ denotes at the $5 \%$ level, a (***) at the $1 \%$ level. 
Table 14: The Impact of Immigration on Median Wages

\begin{tabular}{|l|l|l|l|l|l|l|}
\hline \multicolumn{7}{|c|}{ Dample: Male 25-45 in t-1, 35-55 in t } \\
\hline $\begin{array}{l}\text { Initial } \\
\text { occupation }\end{array}$ & $\begin{array}{c}\text { All } \\
\text { Blue-Collar }\end{array}$ & Tradable & $\begin{array}{c}\text { Non- } \\
\text { tradable }\end{array}$ & Construction & $\begin{array}{c}\text { Non-tradable } \\
\text { Low-Skill }\end{array}$ & $\begin{array}{c}\text { Construction } \\
\text { Low-Skill }\end{array}$ \\
\hline & \multicolumn{7}{|c|}{ Dependent variable: change in median daily wages } \\
\hline & \multicolumn{7}{|c|}{ Balanced Sample including Location and Occupation movers } \\
\hline$\Delta p_{l t}$ & $-0.112^{* * *}$ & $-0.104 * *$ & $-0.099^{* * *}$ & $-0.168^{* *}$ & $-0.196^{* *}$ & $-0.320^{* *}$ \\
\hline & $(0.032)$ & $(0.045)$ & $(0.037)$ & $(0.072)$ & $(0.094)$ & $(0.132)$ \\
\hline & \multicolumn{7}{|c|}{ Balanced Sample of Stayers } \\
\hline$\Delta p_{l t}$ & $-0.067 * *$ & $-0.101^{* *}$ & $-0.110^{* *}$ & $-0.180^{*}$ & $-0.196^{* *}$ & $-0.196^{* *}$ \\
\hline & $(0.030)$ & $(0.048)$ & $(0.053)$ & $(0.095)$ & $(0.094)$ & $(0.093)$ \\
\hline & $-0.117 * *$ & $-0.153^{* *}$ & $-0.117 * *$ & $-0.168^{*}$ & $-0.191 * *$ & -0.151 \\
\hline$\Delta p_{l t}$ & $(0.048)$ & $(0.071)$ & $(0.050)$ & $(0.090)$ & $(0.080)$ & $(0.134)$ \\
\hline
\end{tabular}

Note: All regressions use 1188 observations and include a full set of regions and time fixed effects and are estimated with 2SLS. Additional controls are included in the regressions. Standard errors are clustered at the commuting zone level. Regressions are weighted by $\left(1 / N_{k l t}+1 / N_{k l t-1}\right)^{-1 / 2}$ where $N_{k l t}$ represents the size of the occupation group $k$ in location $l$ and year $t$. A $\left(^{*}\right)$ denotes statistical significance at the $10 \%$ level, a $\left(^{* *}\right)$ denotes at the $5 \%$ level, a (***) at the $1 \%$ level. 
Table 15: Sensitivity of the Effects of Immigration on Average Daily wages to alternative specifications

\begin{tabular}{|c|c|c|c|c|c|c|c|}
\hline & Blue-Collar & Tradable & Non-tradable & Construction & $\begin{array}{l}\text { Non- } \\
\text { tradable low } \\
\text { skill }\end{array}$ & $\begin{array}{l}\text { Construction } \\
\text { low skill }\end{array}$ & $\mathrm{N}$ \\
\hline & \multicolumn{7}{|c|}{ upation movers } \\
\hline \multirow[t]{2}{*}{ 1. No covariates } & $-0.111^{* * *}$ & $-0.086 * * *$ & $-0.122 * * *$ & $-0.181 * * *$ & $-0.187 * * *$ & $-0.337 * * *$ & 1188 \\
\hline & $(03033)$ & $(0.030)$ & $(0.040)$ & $(0.068)$ & $(0.061)$ & $(0.098)$ & \\
\hline \multirow[t]{2}{*}{ 2. Covariates } & $-0.104 * * *$ & $-0.091 * *$ & $-0.109 * * *$ & $-0.187 * *$ & $-0.194 * *$ & $-0.264 * *$ & 1188 \\
\hline & $(0.032)$ & $(0.044)$ & $(0.039)$ & $(0.075)$ & $(0.087)$ & $(0.121)$ & \\
\hline \multirow[t]{2}{*}{ 3. Exclude largest cities } & $-0.099 * * *$ & $-0.086 * *$ & $-0.093 * * *$ & -0.073 & $-0.121^{*}$ & -0.055 & 1176 \\
\hline & $(0.031)$ & $(0.042)$ & $(0.033)$ & $(0.048)$ & $(0.064)$ & $(0.061)$ & \\
\hline \multirow[t]{3}{*}{ 4. Without weights } & $-0.138^{* * *} *$ & $-0.169 * * *$ & $-0.104 * *$ & -0.056 & -0.305 & 0.082 & 1188 \\
\hline & $(0.044)$ & $(0.065)$ & $(0.045)$ & $(0.056)$ & $(0.197)$ & $(0.139)$ & \\
\hline & \multicolumn{7}{|c|}{ B. Cross-sectional sample } \\
\hline \multirow[t]{2}{*}{ 1. No covariates } & $-0.105^{* * *}$ & $-0.119 *$ & $-0.118^{* * *}$ & $-0.158 * *$ & $0.162 * * *$ & $-0.213 * *$ & 1188 \\
\hline & $(0.040)$ & $(0.047)$ & $(0.043)$ & $(0.068)$ & $(0.060)$ & $(0.094)$ & \\
\hline \multirow[t]{2}{*}{ 2. Covariates } & $-0.090 * *$ & $-0.118 *$ & $-0.122 * *$ & $-0.171 *$ & $-0.195 * *$ & -0.105 & 1188 \\
\hline & $(0.046)$ & $(0.066)$ & $(0.052)$ & $(0.092)$ & $(0.078)$ & $(0.132)$ & \\
\hline \multirow[t]{2}{*}{ 3. Exclude largest cities } & $-0.099 * * *$ & $-0.086 * *$ & $-0.093^{* * *}$ & -0.073 & $-0.121^{*}$ & -0.055 & 1176 \\
\hline & $(0.031)$ & $(0.042)$ & $(0.033)$ & $(0.048)$ & $(0.064)$ & $(0.061)$ & \\
\hline \multirow[t]{2}{*}{ 4. Without weights } & $-0.145^{* * *}$ & -0.187 & $-0.160 * *$ & -0.056 & $-0.312^{*}$ & 0.222 & 1188 \\
\hline & $(0.056)$ & $(0.165)$ & $(0.069)$ & $(0.124)$ & $(0.188)$ & $(0.156)$ & \\
\hline
\end{tabular}

Note: All regressions use 1188 observations and include a full set of regions and time fixed effects and are estimated with 2SLS. Additional controls are included in the regressions. Standard errors are clustered at the commuting zone level. Regressions are weighted by $\left(1 / N_{k l t}+1 / N_{k l t-1}\right)^{-1 / 2}$ where $N_{k l t}$ represents the size of the occupation group $k$ in location $l$ and year $t \quad(*)$ denotes statistical significance at the $10 \%$ level, a (**) denotes at the $5 \%$ level, a (***) at the $1 \%$ level. 